\title{
Jeolojik Bariyer Olarak Faylar, Örnek Çalışma: Çiğli Evka-5 Heyelanı (İzmir)
}

\author{
Faults as Geological Barrier, A Case Study: Çiğli Evka-5 Landslide (Izmir) \\ Cem KINCAL, Tümay KADAKÇI KOCA, Mehmet Yalçın KOCA \\ Dokuz Eylül Üniversitesi, Mühendislik Fakültesi, Jeoloji Mühendisliği Bölümü, IZMİR
}

Geliş (Received): 17 Ocak (January) 2017, Düzeltme (Revised): 03 Nisan (April) 2017, Kabul (Accepted): 14 Nisan (April) 2017

\section{ÖZ}

İzmir bölgesindeki heyelanlar, yüksek yağışın, faylanmanın ve oldukça ayrışmış volkaniklerin varlığının yanı sıra yol genişletilmesi, temel kazıları ve arsa temin etmek için eski dere yataklarının doldurulması gibi büyük ölçekli insan etkinlikleri nedeniyle de oluşmaktadır. Tüm bu aktiviteler kaya kütlelerinin yenilmeye karşı hassasiyetini arttırmakta veya önceden değişik nedenlerle hareket etmiş kaya ve zemin kütlelerini yeniden harekete geçirmektedir. Çiğli Evka-5 heyelanı, kütle hareketinin yönüyle fayın eğim yönünün örtüştüğü fay denetimli bir heyelandır. Kütle hareketinin tipi moloz akmasıdır. Aglomera ve filiş taban kayasında ters ve normal fayların geometrileri nedeniyle bir hendek/cep oluşumu belirlenmiş ve bu cebin heyelan mekanizmasıyla ilişkisi incelenmiştir. Jeolojik bariyer olarak ters fayın sahada olası bir derin kaymayı engellediği görülmüştür. Sı ̆̆ derinlikte $(8-15 \mathrm{~m})$ gelişen heyelanın önlenmesine yönelik önerilen kazıkların yer seçiminde de ters fayın sağlam kaya özelliğindeki yükselen bloğu yarar sağlamıştır. Heyelan sahasında 12 noktada 30-70 m'ye kadar karotlu zemin sondajları açılmış ve 3 kuyuda presiyometre deneyleri ve 2 kuyuda ise inklinometre okumaları yapılmışıtır. Kayma dairesi inklinometre okumaları; presiyometre ölçümleri, sondaj logları ve jeomorfolojik yapı değerlendirilerek bulunmuştur. Ölçümler ve arazi araştırmalarıla bulunan kayma dairesinin yeri, şev stabilite analizlerinden elde edilenle karşılaştırılmıştır.

Anahtar Kelimeler : Çiğli (İzmir), Fay, Heyelan, Jeolojik Bariyer, Mühendislik Jeolojisi.

\section{ABSTRACT}

The landslides in Izmir region occur due to high rainfall, faulting, the presence of highly weathered volcanics as well as large-scale human activities such as road widening, foundation excavations and filling in old creek beds to form building site. All of these activities increase the vulnerability of rock masses to failure or reactivate rock and soil masses which fail due to various reasons mentioned beforehand. The Çiğli Evka-5 landslide is controlled by the faults where the sliding direction of the mass movement coincides with the dip direction of fault. Mass movement which developed on the disturbed hanging wall of the fault occurred in the type of earthflow. A trench/pocket was formed due to the geometries of the normal and reverse faults developed in agglomerate and the flysch base rocks. The relationship between the hanging wall fault pocket and the mechanism of the landslide is investigated in this work. It is also determined that the reverse fault as a geological barrier blocked a possible deep sliding in the area. It was benefitted from the rising block of the reverse fault revealing good rock mass characteristics during the decision phase of the location of proposed piles to prevent the landslide at shallow depth $(8-15 \mathrm{~m})$. Subsurface 
Kıncal, Kadakçı Koca, Koca

geotechnical investigations in the landslide area included; 12 borings (core drillings) down to 30-70 $\mathrm{m}$ from the ground surface, inclinometric readings in 2 borings, and pressuremeter measurements in 3 borings. Slip circle was defined on the basis of inclinometric readings, pressuremeter measurements, core descriptions (geotechnical logging), and geomorphologic structure. The location of the slip surface defined by the measurements and in-situ survey is compared with that of derived from the slope stability analyses.

Keywords : Çiğli (İzmir), Fault, Landslide, Geological Barrier, Engineering Geology.

\section{GÍRIŞ}

İzmir ve yöresinde meydana gelen heyelanların \% 39.6's1 andezitik karakterdeki piroklastik kayaçlarda gelişmiştir ve bunlar çoğunlukla mal kayıplarına neden olmuştur (Tarcan ve Koca, 2001; Kincal vd., 2009; Akgün vd., 2012). Bu heyelanların en büyükleri İzmir Körfezi'nin güneyinde Kadifekale yöresinde, kuzeyinde ise Çiğli ve Cumhuriyet semtlerinde yer almaktadır (Şekil 1). Kadifekale-Vezirağa ve Çiğli Evka-5 heyelanları, kütle hareketinin yönüyle fayın eğim yönünün örtüştüğü fay denetimli heyelanlardır. Çiğli heyelan sahası 1/5000 ölçekli K18-22d ve 1/1000 ölçekli K1822d-1b paftalarının KB'da, İzmir Körfezi'nin kuzeyinde Çiğli ilçe merkezinin sınırları içerisinde yer alır (Şekil 1). Heyelan Kızmezarı Tepe'nin KB'ya eğimli, basamaklı morfolojiye sahip yamaçları boyunca meydana gelmiştir. Heyelanın etki sahası $114.600 \mathrm{~m}^{2}$ dir. Heyelanın kayma yönündeki (K55B) uzunluğu $335 \mathrm{~m}$, bu yöne dik KD-GB yönündeki genişliği ise 345 m'dir. Heyelanın taç noktası $(285 \mathrm{~m})$ ve topuğu arasındaki kot farkı 95 m'dir. Bu değerler dikkate alındığında genel yamaç açısı yaklaşık $15^{\circ}-16^{\circ}$ dir. Yapılaşma öncesi topoğrafya incelendiğinde, KB-GD yönünde, birbirine paralel uzanmış dere yataklarının varlığı dikkati çeker (Şekil 1). Günümüzde heyelan sahasının KD'sunu sınırlayan dere yatağı hariç, diğerleri arsa olarak değerlendirilmek üzere doldurulmuş, gömülü dere yatağı durumundadır ve yüzeyden izlenememektedir. Dere yataklarının akış yönleri KB'ya doğrudur.

Çiğli Toki Evleri bölgesinde heyelan hareketleri 2014 Aralık ve 2015 Ocak ayları arasındaki yoğun yağışlarla birlikte başlamıştır (Şekil 2). Heyelan nedeniyle binaların bahçelerinde, çitlerde deformasyonlar ve yollarda da gerilme çatlakları oluşmuştur. Ocak ayında 8930/1 sokak üzerinde yer alan C-10, C-11, ve C-12 nolu apartman bloklarının bazı dairelerinde verevine gelişmiş çatlaklar oluşmuştur. Binalar AFAD yetkilileri tarafindan da incelenmiş ve tahliyeleri istenmiştir. Heyelanın etki alanı içerisinde 9 adet ve taç noktasının gerisinde 4 adet olmak üzere toplam 13 adet apartman bloğu, 1 dükkân, 1 oyun parkı, 1 otobüs durağı ve 1 ilkokul binası yer almaktadır. Heyelan nedeniyle oluşan çatlaklardaki açılmalar GPS yardımıyla takip edilmiştir. 50 noktada, haftada iki kez ölçüm yapılarak kayıtlar alınmıştır. Ölçümler 2015 Ağustos - Ekim ayları arasında yapılmıştır. Esas kayma bölgesiyle çökme bölgesi arasındaki maksimum toplam yer değiştirme miktarı 42 cm olarak ölçülmüştür. Ayrıca taç bölgesinde, V-şeklindeki kayma düzlemi boyunca yer değiştirmeler meydana gelmiş, asfalt yolda 50 cm'ye erişen düşümler gerçekleşmiştir (Şekil 3). 


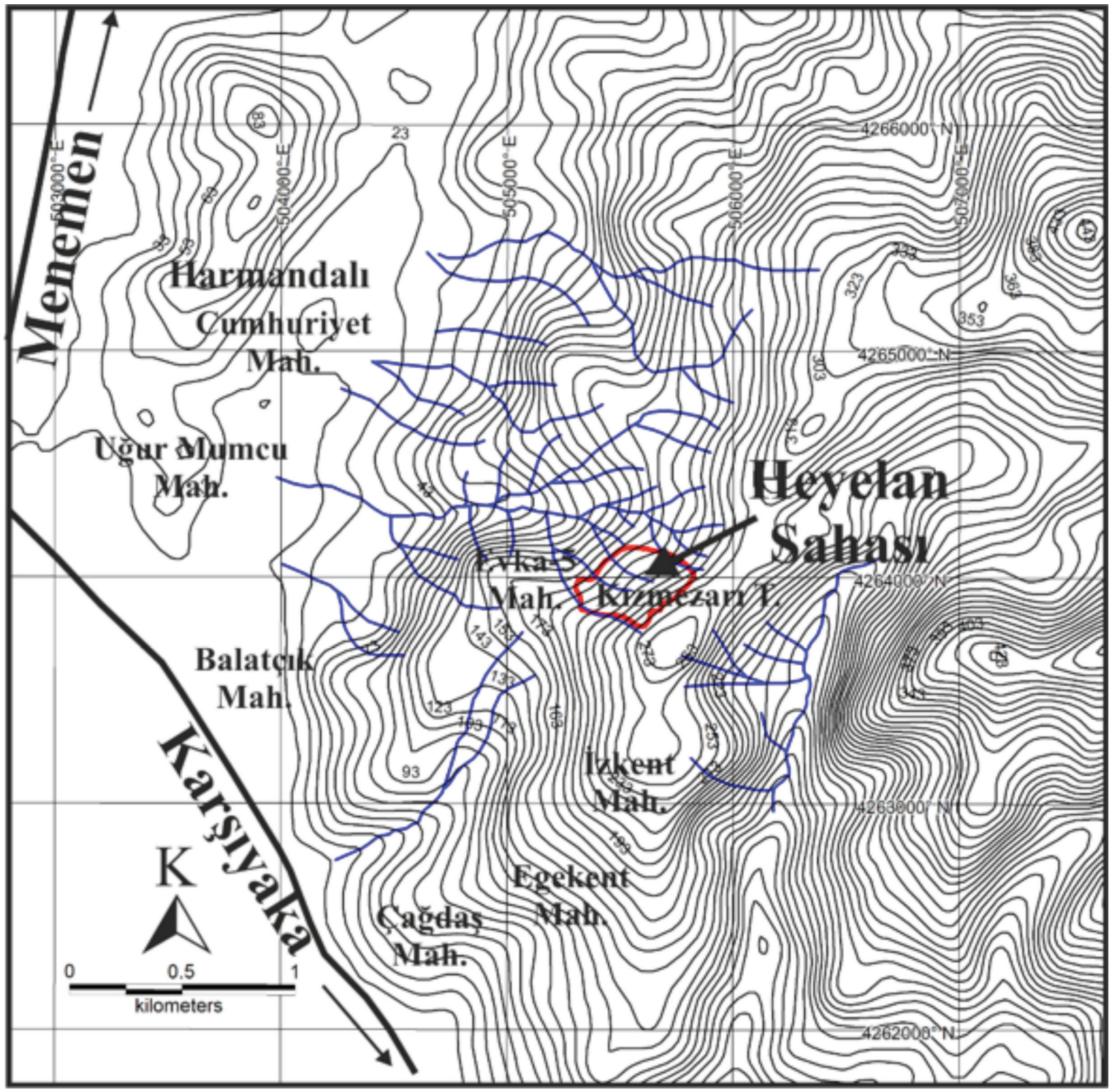

Şekil 1. Heyelan sahasının 1/25000 ölçekli topoğrafik haritadaki konumu.

Figure 1. Location of the landslide area on the topographic map with a scale of 1/25000.

C-10, C-11 ve C-12 nolu apartman bloklarının bazı dairelerinde verev şekilli çatlaklar, binaların etrafında yer alan kenar dolgularında ötelenmeler ve heyelanın kabarma bölgesinde, döşeme taşlarında da kabarma nedeniyle yükselmeler şeklinde deformasyonlar gözlenmiştir. Tüm bu deformasyonlara karşın, binalarda düşeyden sapma veya geriye doğru yaslanma şeklinde dönel kayma hareket belirtileri gözlenmemiştir. 
Kıncal, Kadakçı Koca, Koca

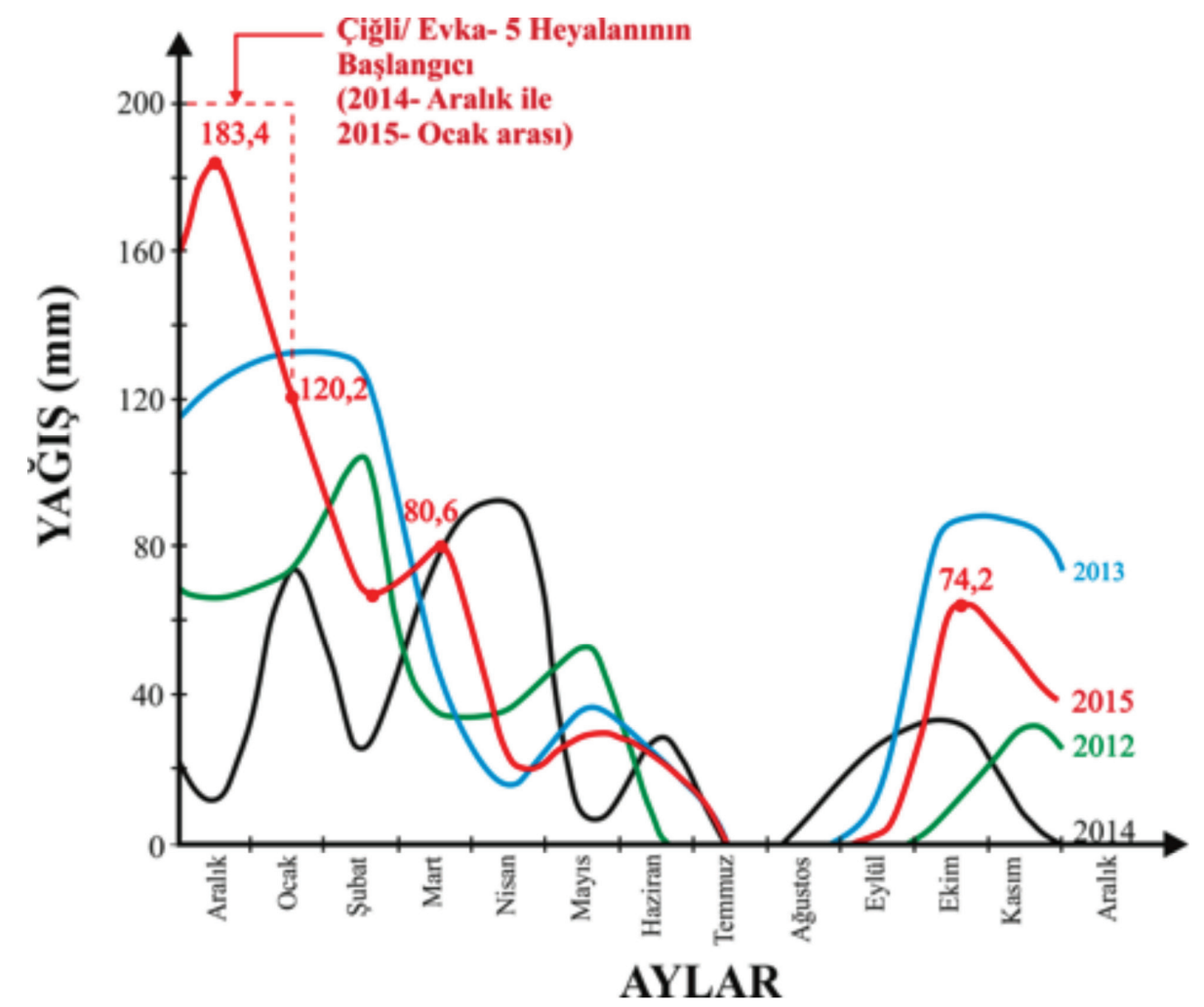

Şekil 2. İzmir için, 2012-2015 yılları arası aylık toplam yağış miktarı ortalaması.

Figure 2. Average amount of monthly total precipitation, for Izmir between 2012 and 2015).

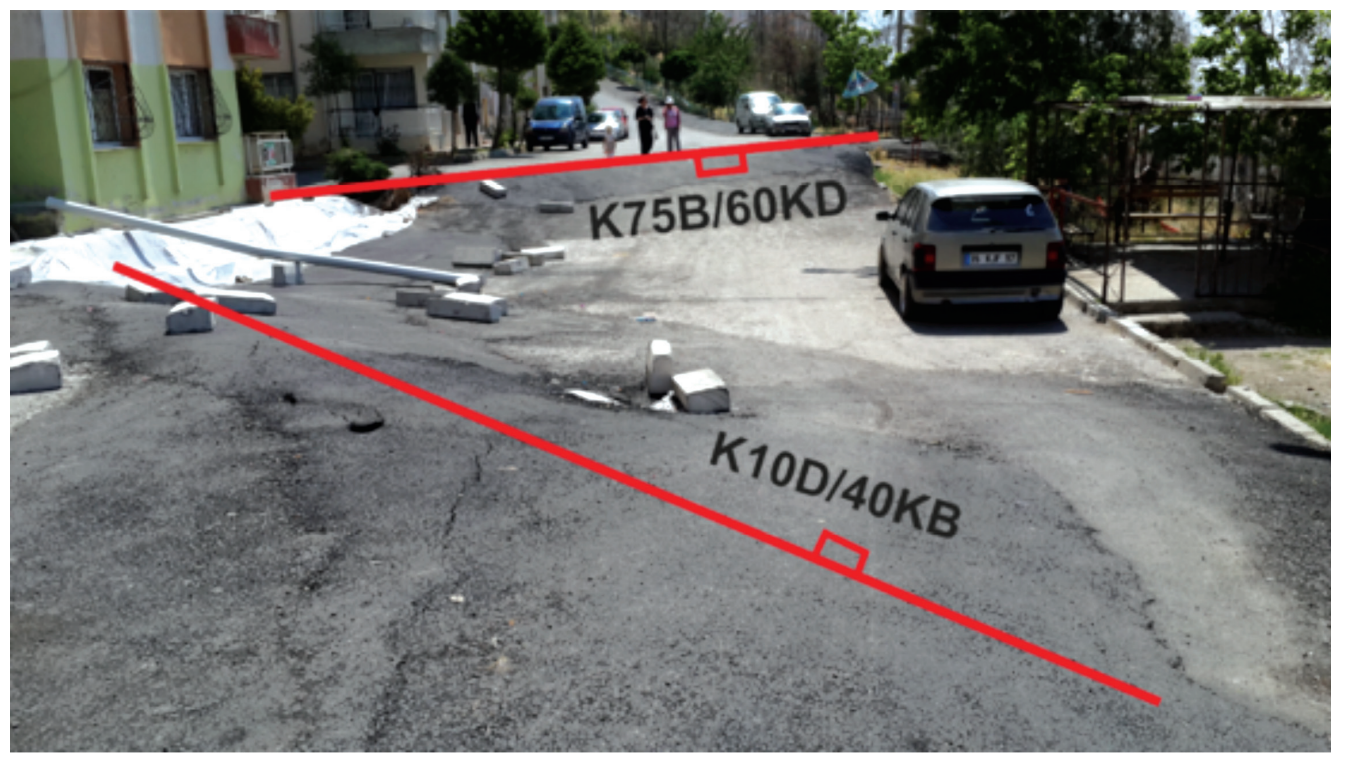

Şekil 3. Çınar apartmanının kuzey cephesinde heyelan nedeniyle oluşan deplasmanlar.

Figure 3. Displacements occurred in the northern face of Çınar apartment due to the landslide. 


\section{YÖNTEMLER}

Heyelan sahasında 12 noktada, derinlikleri 30 ile $70 \mathrm{~m}$ arasında değişen karotlu zemin sondajları açılarak jeolojik birimlerin düşey yöndeki, sondajlardan elde edilen kuyu logları deneştirilerek de yanal yöndeki değişimleri incelenmiştir. Ayrıca karotlar loglanırken fay zonlarının yerleri (fay kili oluşumu ve yoğun çatlaklı zonlar), heyelan kayma dairesinin yer aldığ 1 derinlik ve bu zonların etki mesafeleri araştırılmıştır. Sondajlar, heyelanın çökme, kabarma ve topuk bölgelerinde açılmıştır. Açılan sondajların numaraları, derinlikleri ve heyelanın hangi bölgesinde yer aldığı Çizelge 1 'de verilmiştir. Zemin örnekleri üzerinde ASTM D. 422-63 (2007)'ye göre tane boyu dağılımı, ASTM (1971)'e göre ise kıvam limitleri deneyleri yapılmıştır. Aglomera ayrışma ürünü killi zeminlerin makaslama dayanım parametrelerinin değişiminin saptanmasına yönelik olarak konsolidasyonsuz-drenajsız (UU) ve konsolidasyonlu-drenajlı (CD) makaslama deneyleri ASTM (1979a)'ya göre yapılmıştır. Deney cihazıyla ilgili bilgiler Çizelge 1'de gösterilmiştir. Kalıcı makaslama kapasiteli ve deformasyon denetimli zemin makaslama cihaz1 kullanılarak gerçekleştirilen konsolidasyonludrenajlı makaslama deneyleriyle belirlenmiş 12 adet normal ve makaslama gerilmesi değerleri üç adet yenilme zarfının tayini için ayrıca değerlendirilmiş ve bu değerlendirmede doğrusal (Mohr-Coulomb) ve Eşitlik 1'de verilen eğrisel yenilme ölçütleri kullanılmıştır:

$\tau=\mathrm{A}\left(\sigma_{\mathrm{n}}\right)^{\mathrm{B}}$

Konsolidasyonlu-drenajlı deneylerden elde edilen makaslama dayanım parametrelerinin şevlerin uzun dönemli duraylık analizlerinde kullanılması hedeflenmiştir.

Çizelge 1. Sondaj derinlikleri ve yer aldıkları heyelan bölgesi.

Table 1. Depths of the boreholes and their locations in the landslide area.

\begin{tabular}{cccc}
\hline $\begin{array}{c}\text { Sondaj } \\
\text { No }\end{array}$ & $\begin{array}{c}\text { Sondaj derinliği } \\
(\mathbf{m})\end{array}$ & Heyelan bölgesi & $\begin{array}{c}\text { Topoğrafik } \\
\text { kot (m) }\end{array}$ \\
\hline SK-1 & 44 & Kayma bölgesi-çökme bölgesi sınırı & 240 \\
SK-2 & 50 & Kayma bölgesi-çökme bölgesi sınırı & 242 \\
SK-3 & 50 & Kayma bölgesi-çökme bölgesi sınırı & 243 \\
SK-4 & 55 & Çökme bölgesi & 233 \\
SK-5 & 30 & Çökme bölgesi & 226 \\
SK-6 & 70 & Çökme bölgesi & 216 \\
SK-7 & 50 & Kabarma bölgesi & 222 \\
SK-8 & 44 & Çökme bölgesi & 218 \\
SK-9 & 45 & Kabarma bölgesi & 220 \\
SK-10 & 48 & Kabarma bölgesi & 217 \\
SK-11 & 50 & Akma bölgesi & 201.5 \\
SK-12 & 52 & Akma bölgesi & 202 \\
\hline
\end{tabular}


Kıncal, Kadakçı Koca, Koca

Çizelge 2. Deney aletlerinin özellikleri.

Table 2. Features of the experimental devices.

\begin{tabular}{|c|c|c|c|c|c|c|}
\hline \multirow[b]{2}{*}{ Adı } & \multicolumn{2}{|c|}{ Deformasyon hızı değişimi } & \multicolumn{4}{|c|}{ Yük halkası değişimi } \\
\hline & $\begin{array}{c}\text { Aralığl } \\
(\mathbf{m m} / \mathbf{d a k})\end{array}$ & Adedi & $\begin{array}{l}\text { Aralığ } \\
(\mathrm{kg})\end{array}$ & Adedi & $\begin{array}{l}\text { Numune boyutları } \\
\text { (cm) }\end{array}$ & Deney türü \\
\hline $\begin{array}{c}\text { Direkt makaslama } \\
\text { (Wykeham Farrance } \\
\text { marka) }\end{array}$ & 0.0020 & 25 & 200 & 5 & $6 * 6 * 2$ & Drenajlı \\
\hline $\begin{array}{l}\text { Serbest sıkışma dayanımı } \\
\text { (Soiltest Chicago AP-170 } \\
\text { Marka) }\end{array}$ & 0.0006 & 25 & 200 & 5 & - & Drenajsız \\
\hline
\end{tabular}

Kuyularda yeraltı suyu derinlikleri iyona duyarl1, kablolu derinlik ölçerler kullanılarak ölçülmüştür. Bu çalışmalara ek olarak, kuyularda yerinde deneyler (İnklinometre ölçümleri ve presiyometre deneyleri) gerçekleştirilmiştir. Böylece, yerinde deneylerle kuyu boyunca geçilen zemin seviyelerinin jeoteknik özellikleri hakkında ayrıntılı bilgi toplanmıştır. İnklinometre ölçümleri, yüzey altındaki yanal deformasyonları ölçmek için kuyu içinde gerçekleştirilen bir deneydir (ASTM D4622-86 (1993)). Kayma dairesinin geçtiği yeri/zonu tespit etmek için iki kuyuda (SK-5 ve SK-8 sondaj kuyularında) inklinometre okumaları, buna ek olarak, 3 kuyuda da presiyometre deneyleri yapılmıştır. Presiyometre deneyi, uygulanan basinca karşı zeminde oluşan hacimsel deformasyon değerlerinin belirlenmesi ilkesine dayanır (ASTM D 4719). Kuyu çeperlerinde yer alan zeminin gerilme-deformasyon $(\sigma-\varepsilon)$ özelliği araştırılır. Araştırmada kullanılan presiyometre tipi, Menard Presiyometresi'dir. Presiyometre deneyi, şev stabilitesi çalışmalarında kayma zonlarının belirlenmesinde kullanılmakta olup, limit basınç (PL), presiyometre deformasyon modülü (Em), içsel sürtünme açısı $(\phi)$, kohezyon (c), ve presiyometre kayma modülü (G) gibi parametreler aşağıdaki eşitlikler ile belirlenmektedir.
$\mathrm{G}=E_{p} / 2(1+v)$

$\mathrm{E}=E_{m} / \alpha$,

Burada $\mathrm{E}_{\mathrm{m}}$ presiyometre deformasyon modülüdür $\left(\mathrm{E}_{\mathrm{m}}=\mathrm{k} \times \Delta P / \Delta V\right) \cdot \alpha$; zemin cinsine ve $\mathrm{E}_{\mathrm{m}} / \mathrm{P}_{\mathrm{L}}{ }^{*}$ oranına bağl reolojik faktördür. $\mathrm{P}_{\mathrm{L}}^{*}$; ise net limit basınçtır.

Heyelanın araştırılması çalışmaları için toplamda 9 hat üzerinde elektrik rezistivite tomografi (ERT) ve 8 hat üzerinde de aktif kaynak yüzey dalgası (MASW) çalışmaları yapılmıştır. Hem ERT hem de MASW ölçümlerinin alındığg hatlar seçilirken, maksimum derinlik ve veri kalitesi parametreleri dikkate alınmıştır. Elektrik rezistivite tomografi yöntemi, farkl1 zemin ve kayaların elektrik dirençlerindeki değișimler üzerine temellendirilmiştir. Bir zeminin rezistivitesi, su içeriği ve tuz konsantrasyonu arttığı için azalır. Suya doygun killer, suyundaki serbest iyonların ve boşluk suyu basıncinın göreceli yüksek olması nedeniyle düşük rezistivite değerleri verir. Rezistivite değerleri çamurtaşlarında $20-60 \cap m$, killi, siltli zeminlerde ise (suya doygun koşullarda) $1.5-15 \cap m$ mertebesindedir (Hunt, 2005). Heyelan sahasinda hat uzunlukları $97 \mathrm{~m}$ ile $235 \mathrm{~m}$. arasında değişen jeofizik profilleri boyunca ölçümler alınmıştır. ERT hatlarının toplam uzunluğu $1820 \mathrm{~m}$ 'dir. $\mathrm{Bu}$ ölçümlerden yeraltı suyunun konumu da 
belirlenmiş ve sondajlardan elde edilen yeraltı suyu derinlik değerleriyle karşılaştırılmıştır. Uygulamada alan durumuna göre 6 nolu serim hariç (elektrot sayısı 36 alınmıştır), diğer tüm serimlerde 48 elektrot sistemiyle ölçü alınmıştır ve 2.5 m elektrot açıklığında maksimum 40 - 45 $\mathrm{m}$ derinliğe kadar veri toplanmıştır.

MASW çalışmaları 8 hat üzerinde, 24 kanallı uygulamayla gerçekleştirilmiştir (ERT-8 hattında MASW serimi yapılmamıştır). Uygulamada alan durumuna göre birbirini izleyen serimler halinde veri toplanmıştır. Yapılan çalışmada yalnızca 4 nolu serimde jeofon aralığ $3 \mathrm{~m}$, diğer serimlerde ise $2 \mathrm{~m}$ olarak seçilmiştir. MASW hatlarının toplam uzunluğu 1853.5 m'dir. Bu ölçümlerle Vsdalga hızının derinlikle değişimi incelenmiştir. Ayrıca yeraltındaki kütle yer değiştirmeleri de yorumlanmıştır.

Şevlerin duraylılığını değerlendirmek için kullanılan birçok geleneksel ve sayısal teknikler vardır. Geleneksel teknikler limit denge tekniklerini ve kinematik analizleri içerir. Heyelan sahasının duraylık incelemeleri iki boyutlu geleneksel limit denge tekniği (the two dimensional conventional limit equilibrium) kullanılarak gerçekleştirilmiştir. Limit denge yöntemi (LEM) güvenlik sayısını (FoS) tahmin etmek için olası kayma yüzeyi üzerinde yer alan kaymasımuhtemelkütleyi düşey farklıbüyüklükte dilimlere ayırarak inceler. Dairesel ve dairesel olmayan limit denge yöntemleri sadece yenilmesi muhtemel veya kayma yenilmesine uğramış tüm kütlenin dengesini dikkate alır. Yöntem yüzeyin makaslama dayanımıyla bu yüzey üzerinde hareket eden (aktif olan) makaslama gerilmesi arasındaki oran olan güvenlik sayısını kritik kayma yüzeyi boyunca belirler. Dilim yöntemi üzerine temellendirilmiş olan basitleştirilmiş Bishop Yöntemi, tüm lokasyonlarda güvenlik katsayısını hesaplamak için limit denge analizini kullanır. Bu yöntemde, yenilmenin herhangi bir nokta üzerinde merkezlenmiş dairesel bir kayma yüzeyi üzerinde yer alan kaya/zemin kütlesinin rotasyonuyla (dairesel hareketiyle) meydana geldiği var sayılır. Dilimin kenarına etkiyen kuvvetlerin yatay olduğu düşünülür ve dilimler arası makaslama gerilmelerinin olmadığ 1 kabul edilir (Bishop, 1955). Toplam normal kuvvet her bir dilimin tabanının orta noktasinda tesir eder ve düşey yöndeki kuvvetler toplanarak türetilir. $\mathrm{Bu}$ çalışmada heyelan şevinin limit denge analizi basitleştirilmiş Bishop Yöntemi kullanılarak gerçekleştirilmiştir. Analizler Slide V.6 bilgisayar programı (Rocscience, 2010) kullanılarak yürütülmüştür.

\section{Jeoloji}

İnceleme alanı ve yöresinde temeli, Üst Kretase-Paleosen yaşl1, kumtaşı-şeyl ardalanmasından oluşmuş ve içerisinde değişik büyüklükte kireçtaşı blokları bulunduran "Bornova Karmaşığı”" (filiş) oluşturur. Heyelanın topuğunda, 190-200 m kotlarının altında, sahanın kuzeybatısında yer alan binaların temel kotunda birimin yüzleklerine rastlanır (Şekil 4). Gerek yüzleklerden, gerekse de sondajlardan elde edilen karot tanımlamalarından, karmaşığın kumtaşı baskın bir litolojiden oluştuğu anlaşılmıştır. Kıvrımlı ve kırıklı bir yapıya sahip Bornova Karmaşığı'nın üzerine ayrımlı kaya uyumsuzluğu ile doğrudan Üst MiyosenPliyosen yaşlı, andezitik karakterde Yamanlar Volkanitleri gelir (Akartuna 1962; Kıncal 2005, Şekil 4). Heyelan sahası ve yöresinde andezitik karakterdeki volkanik kayalar; bloklu yapıya sahip aglomeralar ve andezit lavlariyla temsil edilirler. 
Kıncal, Kadakçı Koca, Koca

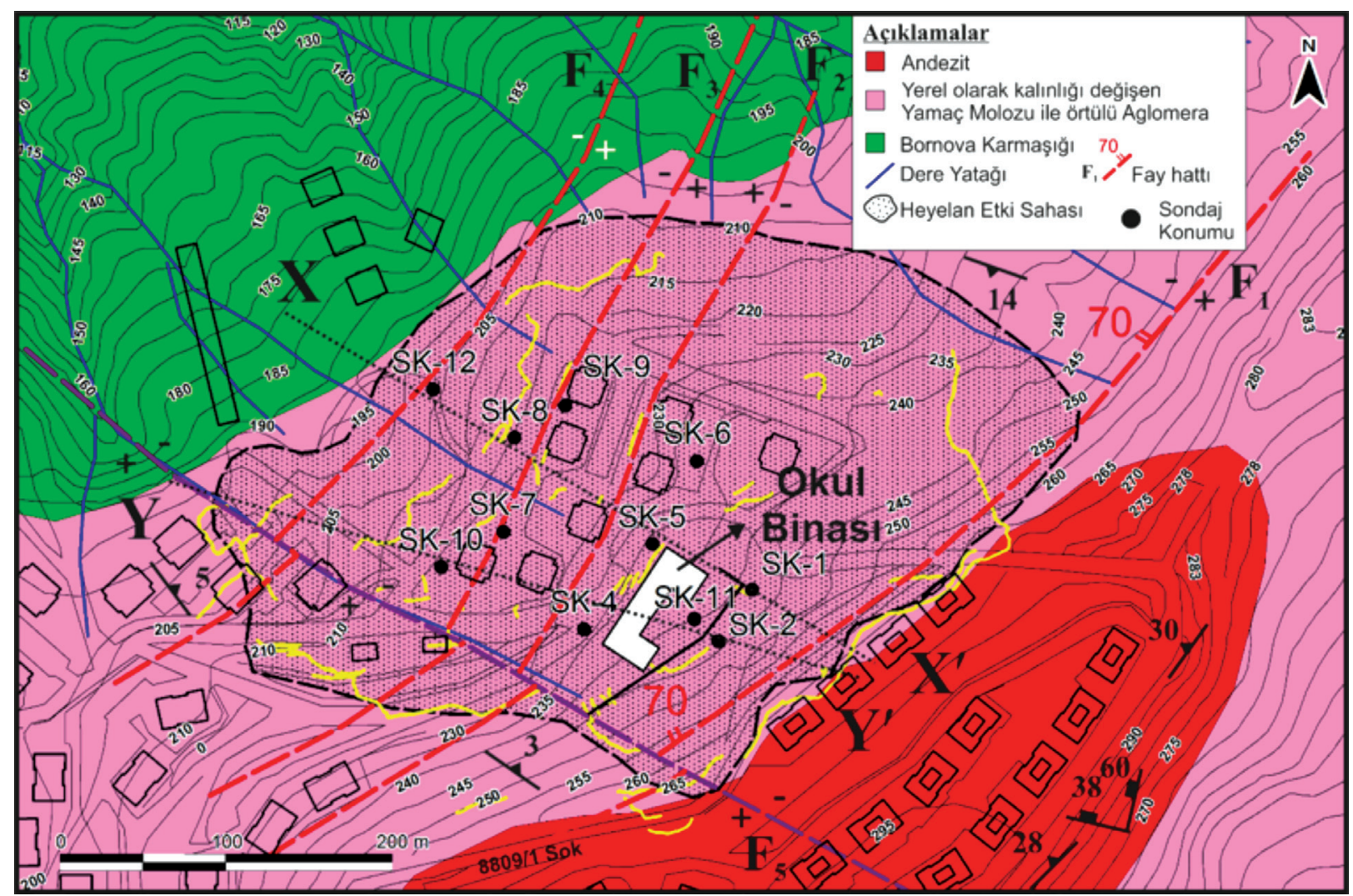

Şekil 4. Heyelan sahasının jeoloji haritası.

Figure 4. Geological map of the landslide area.

Andezitler $270 \mathrm{~m}$ kotlarının üzerinde yer alır. Akma bant yapıları ve soğuma çatlaklarıyla tipiktirler. Aglomeralar $270 \mathrm{~m}$ kotunun altında, 190 m kotuna kadar geniş bir alanda, oldukça veya tamamen ayrışmış olarak yer alırlar. Yer yer yığışım şeklinde ve üzerine geldiği topoğrafyaya bağlı olarak kalın bantlı yerleşim şekilleri gösterirler. Bazen bu bantlarla uyumlu dokanaklara sahip ince, devamlı olmayan düzeyler şeklinde, beyaz renkli tüflerle birlikte gözlenirler. Heyelan sahası ve yöresinde yamaç molozları topoğrafyanın sekiler yaptığı basamak düzlüklerinde ve eski dere yataklarının vadilerinde yer alır. Yamaç molozları; andezit çakıl ve bloklarının kum, silt ve kil boyutu zemin içinde yer aldığı, orta-katı, genellikle nemli bir malzeme özelliğindedir. Heyelan sahasında en tipik ve en kalın olarak, 260 m kotlarında yer alan $F_{1}$ fayının aynasıyla ilkokul binasının yer aldığı arazi kesimi arasında gözlenirler (Şekil 4).

\section{Faylar}

Heyelan sahasında beş adet fay tespit edilmiştir $\left(F_{1}, F_{2}, F_{3}, F_{4}\right.$ ve $F_{5}$ fayları). $F_{1}$ fayı inceleme alanında gözlenen en büyük faydır (Şekil 4). $\mathrm{F}_{5}$ fayı hariç diğer faylar, $\mathrm{F}_{1}$ fayına bağlı olarak gelişmiş basamak faylarıdır. $\mathrm{F}_{1}, \mathrm{~F}_{2}, \mathrm{~F}_{3}$ ve $\mathrm{F}_{4}$ faylarından $\mathrm{F}_{2}$ fayı hariç diğerleri eğim atımlı normal fay özelliği taşımaktadır. $\mathrm{F}_{2}$ ise ters fay özelliği sunar. En genç fay olarak $\mathrm{F}_{5}$ fayı diğer tüm fayları keser konumdadır (Şekil 4). 
Aglomeralar ve Bornova Karmaşı̆̆g'na ait kayaçlar önce $F_{1}, F_{2}, F_{3}, F_{4}$ faylarıyla kırılmış ve atılmıştır (Şekil 5). Daha sonra $\mathrm{F}_{5}$ fayıyla kesilmişlerdir. $F_{1}$ fayı (K 65 D / 71 KB) yaklaşık $4 \mathrm{~km}$ uzunluğunda ve incelenen alanda morfolojiyi denetleyen ana yapisal eleman olarak dikkati çekmektedir (Şekil 1). $F_{1}$ normal fayının düşen bloğu üzerinde diğer faylar $\left(\mathrm{F}_{2}\right.$, $\mathrm{F}_{3}$ ve $\mathrm{F}_{4}$ fayları) yer almaktadır. $\mathrm{F}_{1}$ fayının düşey atımı $48 \mathrm{~m}$, diğer fayların ise 3 - $15 \mathrm{~m}$ arasında değişmektedir. Heyelan sahası içerisinde $\mathrm{F}_{1}, \mathrm{~F}_{2}$, $\mathrm{F}_{3}$ ve $\mathrm{F}_{4}$ faylarının kayma düzlemlerinin eğim yönleri kuzeybatıdır (Şekil 5). $F_{1}$ normal fayı ile $\mathrm{F}_{2}$ ters fay1 $(\mathrm{K} 25 \mathrm{D} / 70 \mathrm{~KB})$ temel kayada farklı fay geometrileri nedeniyle bir hendek/cep oluşumuna neden olmuştur (Şekil 6). Bu yapı $\mathrm{F}_{5}$ fayıyla kesilmiş ve tüm sistem fayın aynasına doğru eğimlenmiştir. $F_{2}$ fayının eğim yönünde Bornova Karmaşığı birimi yükselmiş ve fay zonunda kendinden daha genç aglomeralarla yan yana gelmiştir. Bir diğer anlatımla, fayın düşen bloğu önünde bir cep meydana gelmiştir. Bu cep heyelan sahasının güneydoğusunda $F_{1}$ normal fayıla, kuzeybatısında ise $\mathrm{F}_{2}$ ters fayıyla, KBGD yönünde de $\mathrm{F}_{5}$ fayıyla denetlenmiştir. Cebin yüzeyden $60 \mathrm{~m}$ derinliğe kadar indiği açılan sondajlardan anlaşılmıştır. $F_{5}$ fayı eğim atımlı normal fay özelliğindedir ve heyelan sahasını güneybatıdan sınırlamaktadır (Şekil 5 ve 6).

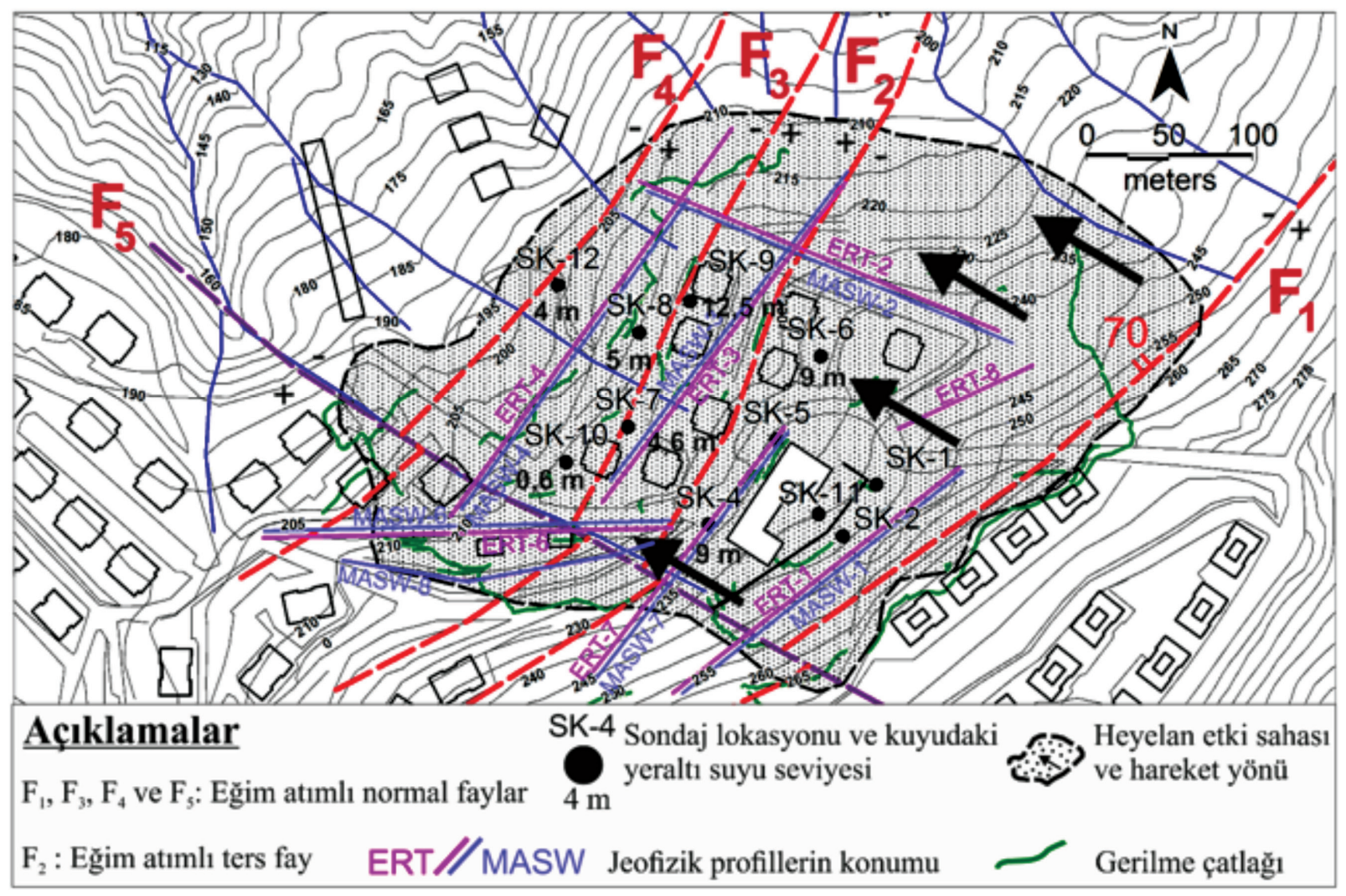

Şekil 5. Evka-5 heyelan sahasında gözlenen faylar, sondaj lokasyonları ve jeofizik ölçüm hatları.

Figure 5. Faults observed in Evka-5 landslide area, borehole locations, and geophysical measurement lines. 
Kıncal, Kadakçı Koca, Koca

$\mathrm{F}_{5}$ fayının diğer faylarla ve heyelanın hareket yönüyle olan konumsal ilişkisi Şekil 7'de verilen stereografik projeksiyon üzerinde gösterilmiştir. $F_{5}$ fayının $F_{1}$ normal fayıyla arasındaki dar açı stereografik net üzerinde $50^{\circ}\left(\widehat{P_{F 1}}-\widehat{P_{F 5}}=50^{\circ}\right), \mathrm{F}_{2}, \mathrm{~F}_{3}$ ve $\mathrm{F}_{4}$ faylarının oluşturduğu kutup yoğunlaşma noktasıyla da $87^{\circ}$ 'lik açı yaptığı $\left(\widehat{P_{F}}-\widehat{P_{F 5}}=87^{\circ}\right)$ belirlenmiştir (Şekil 7). $\mathrm{F}_{5}$ fayı, $\mathrm{F}_{1}$ fayının düşen bloğu üzerinde yer alan $\mathrm{F}_{2}, \mathrm{~F}_{3}$ ve $\mathrm{F}_{4}$ faylarıyla yaklaşı dik açı oluşturmaktadır.

\section{Yeraltı suyu durumu ve jeofizik ölçümler}

Yeraltı suyunun konumu/derinliği bazı sondaj kuyularında (SK-4, SK-6, SK-7, SK-9 ve SK-10 kuyuları) su seviyesi ölçümleri, kuyu açımı sırasında yapılan gözlemler ve toplamda 9 hat üzerinde gerçekleştirilen Elektrik Tomografi Ölçümler (ERT) dikkate alınarak belirlenmiştir. Şekil 5'te hem sondaj yerleri, hem de elektrik rezistivite ölçümlerinin yapıldı $\breve{g} 1$ hatlar gösterilmiştir. Jeofizik ölçüm hatlarının uzunlukları, yönleri ve hangi fayları kestikleri Çizelge 3’te verilmiştir.

$\mathrm{F}_{5}$ fayının doğrultusu boyunca açılan tüm sondajlarda (SK-7, SK-10 ve SK-11) su seviyeleri ya yüzeyde ya da yüzeye çok yakın konumlarda yer almaktadır. Bu durum, $\mathrm{F}_{5}$ fayı boyunca yerleşmiş eski dere yatağının günümüz koşullarında da çalıştığına işaret etmektedir. SK-6 ve SK-4 sondaj kuyularında su seviyesi yüzeydedir (Şekil 8).

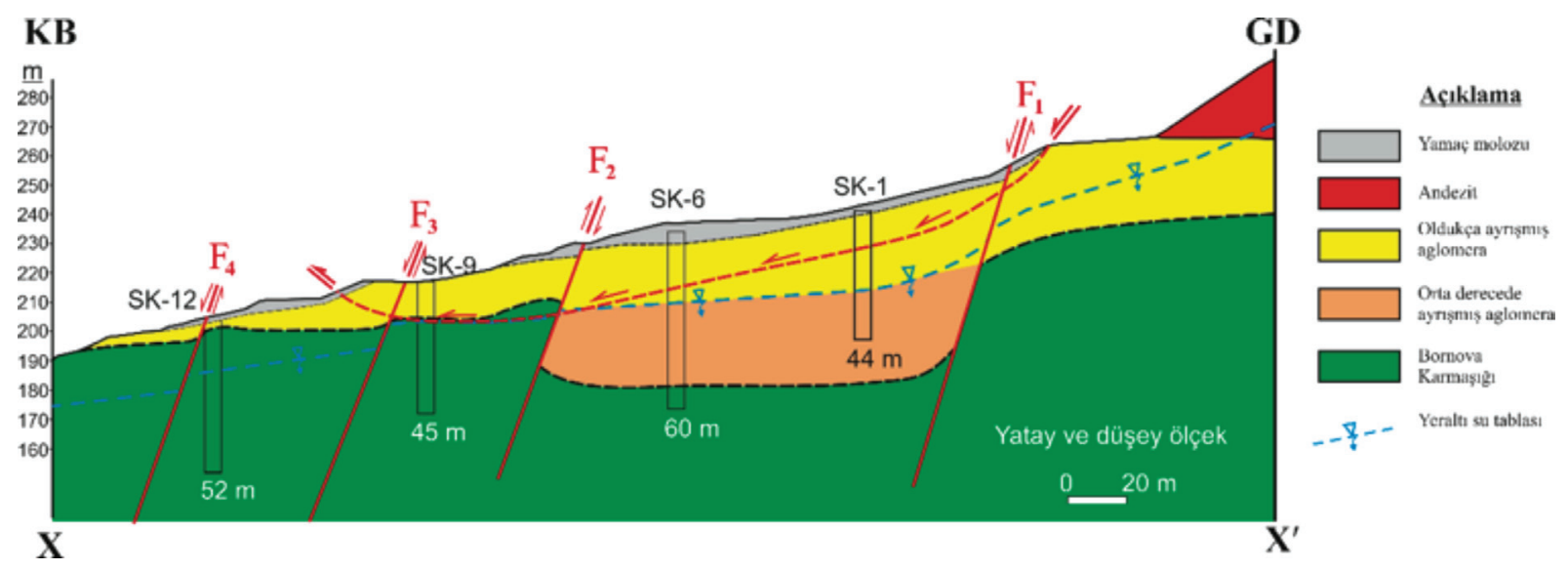

Şekil 6. $\mathrm{F}_{1}$ ve $\mathrm{F}_{2}$ fayları nedeniyle oluşmuş hendeği gösteren jeolojik kesit.

Figure 6. Geological cross-section showing the hanging wall fault pocket occurred due to $F_{1}$, and $F_{2}$ faults. 


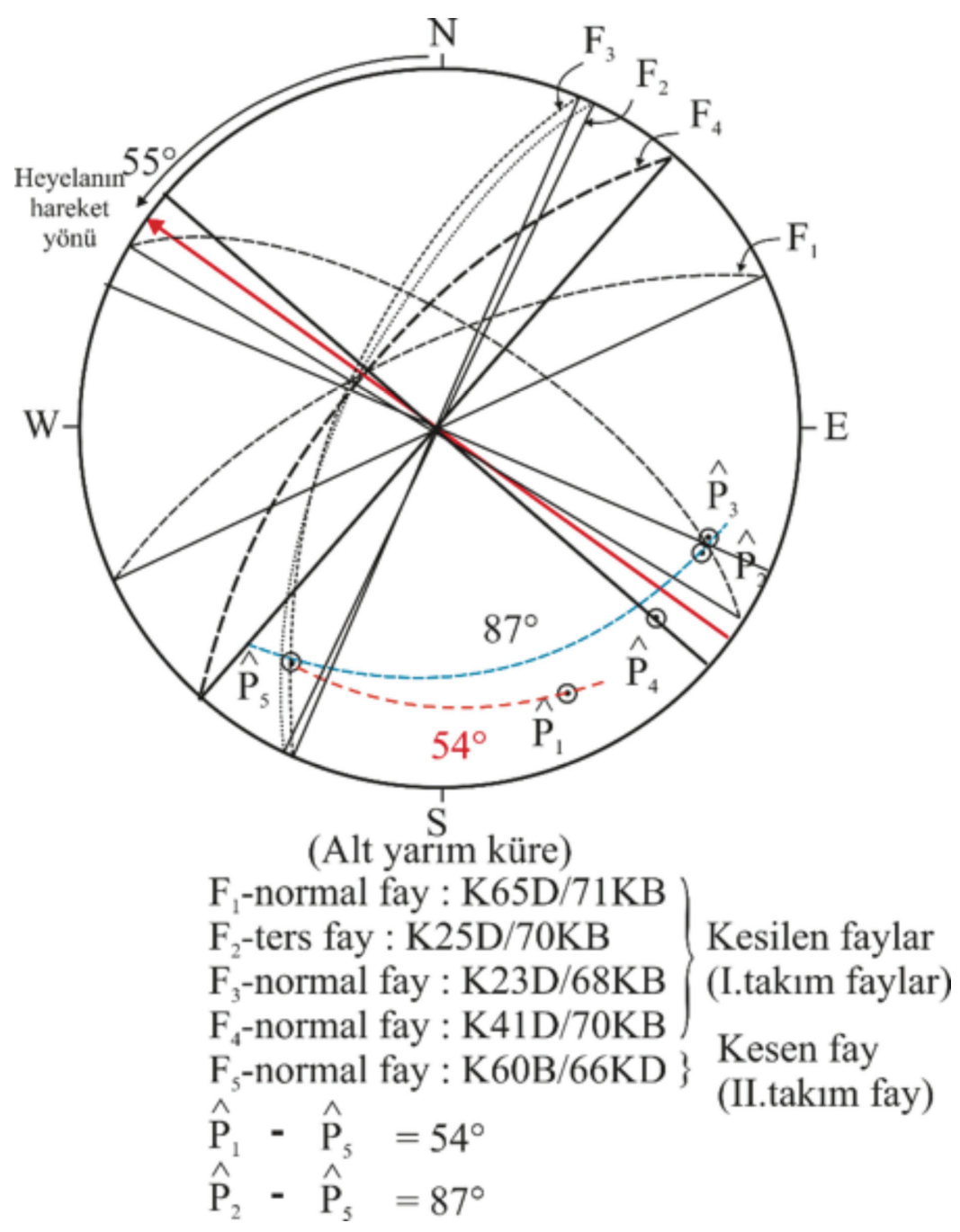

Şekil 7. Heyelan sahasında yer alan fayların büyük daireleri ve heyelanın kayma yönüyle (N 55 W) ilişkileri.

Figure 7. Relationships between the great circles of the faults located in the landslide area and movement direction of the landslide $(\mathrm{N} 55 \mathrm{~W})$.

Aşağıdaki değerlendirme ERT-1 ve ERT7 yönündeki (GB-KD yönünde) su seviyesi değişimini $F_{5}$ fayına göre açıklar. $F_{5}$ fayı heyelan sahasını güneybatıdan sınırlayan jeolojik bir bariyer görevi üstlenir. Fay zonu düşen blok yönünde bir cep/hendek oluşturmuş ve GDKB yönünde de bir geçirimsiz perde/bariyer meydana getirmiştir. Biriken sular fayın batı tarafına kayma aynası boyunca gelişmiş fay kili nedeniyle sizamamaktadır. Bu nedenle fayın tavan bloğunda su seviyesi yükselmektedir. Beslenmesızma dengesi mevsimsel olarak değişmekte ve yeraltı suyu koşullarını belirlemektedir. 
Kıncal, Kadakçı Koca, Koca

Çizelge 3. Elektrik Rezistivite Tomografi (ERT) ölçüm hatlarının özellikleri ve sondajlarda ölçülen yeraltı suyu seviyeleri. Table 3. Features of the electrical resistivity tomography (ERT) measurement lines and groundwater table levels obtained from the boreholes.

\begin{tabular}{|c|c|c|c|c|c|}
\hline ERT-No & $\begin{array}{l}\text { Hat Uzunluğu } \\
\text { (m) }\end{array}$ & $\begin{array}{c}\text { Jeofizik } \\
\text { Hatların Yönü }\end{array}$ & $\begin{array}{c}\text { Hatların } \\
\text { Kestiği } \\
\text { Faylar }\end{array}$ & $\begin{array}{c}\text { Su Seviyesi } \\
\text { (Jeofizik verilere göre) }\end{array}$ & $\begin{array}{c}\text { Sondajlarda Ölçülen } \\
\text { Su Seviyeleri }\end{array}$ \\
\hline ERT-1 & 235 & K $50 \mathrm{D}$ & $\mathrm{F}_{5}, \mathrm{~F}_{1}$ & 0-12 m kalınlığında tünek akifer & $\begin{array}{l}\text { SK-1 ve } 2 \text { 'de } 1.5 \mathrm{~m} \\
\text { (SK-1'de su artezyen } \\
\text { yapt1) }\end{array}$ \\
\hline ERT-2 & 221 & K 70 B & $\mathrm{F}_{2}, \mathrm{~F}_{3}$ & Su yüzeyde (dere yatağı) & - \\
\hline ERT-3 & 218 & K $35 \mathrm{D}$ & $\mathrm{F}_{2}$ & Su seviyesi yüzeyde & $\begin{array}{c}\text { SK-7 } \\
\text { Su seviyesi: } 4.6 \mathrm{~m}\end{array}$ \\
\hline ERT-4 & 235 & K $35 \mathrm{D}$ & $\mathrm{F}_{5}$ & Tünek akifer $0-9 \mathrm{~m}$ & $\begin{array}{c}\text { SK-10 } \\
\text { Su seviyesi: } 0.6 \mathrm{~m}\end{array}$ \\
\hline ERT-5 & 134 & K $60 \mathrm{~B}$ & $\mathrm{~F}_{4}$ & Su yüzeyde (dere yatağı) & - \\
\hline ERT-6 & 169 & K $80 \mathrm{~B}$ & $\mathrm{~F}_{3}$ & Su yüzeyde & - \\
\hline ERT-7 & 235 & K $35 \mathrm{D}$ & $\mathrm{F}_{5}$ & $\begin{array}{l}\text { Tünek akiferle yarı basınçlı akifer } \\
\text { birleşmiş }\end{array}$ & $\begin{array}{l}\text { SK-4 ve SK-5: } \\
\text { Su seviyesi: } 9 \mathrm{~m} \text {. }\end{array}$ \\
\hline ERT-8 & 97 & K 65 D & - & $\begin{array}{l}\text { Su yüzeyde, iki noktada kaynak } \\
\text { oluşumu var. }\end{array}$ & - \\
\hline ERT-9 & 229 & D - B & $\mathrm{F}_{3}$ & YASS derinliği yaklaşık $5 \mathrm{~m}$ & - \\
\hline
\end{tabular}

İlkokulun güneydoğusunda yer alan ERT-1 hatt1 ölçüm sonuçlarına göre, genelde ortamı oluşturan jeolojik birimlerin özdirenç değerleri oldukça düşüktür $(1-5 \mathrm{Ohm} m)$ (Şekil 8). Özellikle hattın 55 - 125 m arasında yer alan kesiminde bu çok belirgindir. Hattın kuzeydoğusundaki devamında, 155 - 190 m'ler arasında da çok düşük özdirenç değerleri ölçülmüştür. Jeofizik kesitte $\mathrm{F}_{5}$ fayının yeri de açık olarak (ERT-1 kesitinin güneybatısından itibaren kuzeydoğuya doğru 80. m'de) gözlenmektedir. Kayma dalgası hızları derine doğru artmaktadır. MASW hattının sonuna doğru Vs $>600 \mathrm{~m} / \mathrm{s}^{\prime}$ lik sismik hızlara erişilmektedir. İlkokul binasının kuzeybatısında yer alan ERT7 hattında, ortamı oluşturan jeolojik birimlerin özdirenç değerlerinin oldukça düşük değerler aldığı (1-6 Ohm m) belirlenmiştir. Hattın 0-150 m'lik kesiminde bu durum açık olarak gözlenir (Şekil 8). MASW ölçümlerinde kayma dalgası hızları $\mathrm{F}_{5}$ fayının kuzeydoğusunda, bir diğer anlatımla cep içinde $150 \leq \mathrm{Vs} \leq 500 \mathrm{~m} / \mathrm{s}$ arasında değerler almıştır. Buna ek olarak, ortamın tamamen suya doygun olduğu da ERT-7 jeofizik kesitinden anlaşılmaktadır. Hendek oluşumunun kesit hattı boyunca, $\mathrm{F}_{5}$ fayından itibaren $75-80 \mathrm{~m}$ devam ettiği de görülmektedir (Şekil 8). Kayma dalgası hızları dikkate alındığında, 0-15 m derinlikte yer alan jeolojik birimler hariç, diğer kaya birimlerinin genelde dayanımlı oldukları görülür. Jeofizik ölçümlerden oldukça düşük özdirenç değerlerinin elde edilmesi, bu birimlerin yeraltı suyundan oldukça etkilendiklerini göstermektedir. Düşük özdirenç değerleri veren jeolojik birimlerin heyelan açısından risk taşıdı̆̆ öngörülebilir.

\section{Laboratuvar deneyleri}

Yüksek plastik kil ve killi siltler üzerinde tek eksenli sıkışma dayanımı $\left(\mathrm{q}_{\mathrm{u}}\right)$ deneyleri 
yapılmıştır. Sıkışma dayanımı ve Atterberg kıvam limitleri deney sonuçları Çizelge 4'te sunulmuştur. Deney sırasında zemin örneklerinin deformasyon eğrileri de elde edilmiştir (Şekil
9). CH-tipi killerde qu değeri $42-46 \mathrm{kPa}$ (orta katı kıvamda), $\mathrm{MH}$ tipi siltler ise $28-32 \mathrm{kPa}$ (yumuşak kıvamlı) olarak ölçülmüştür.

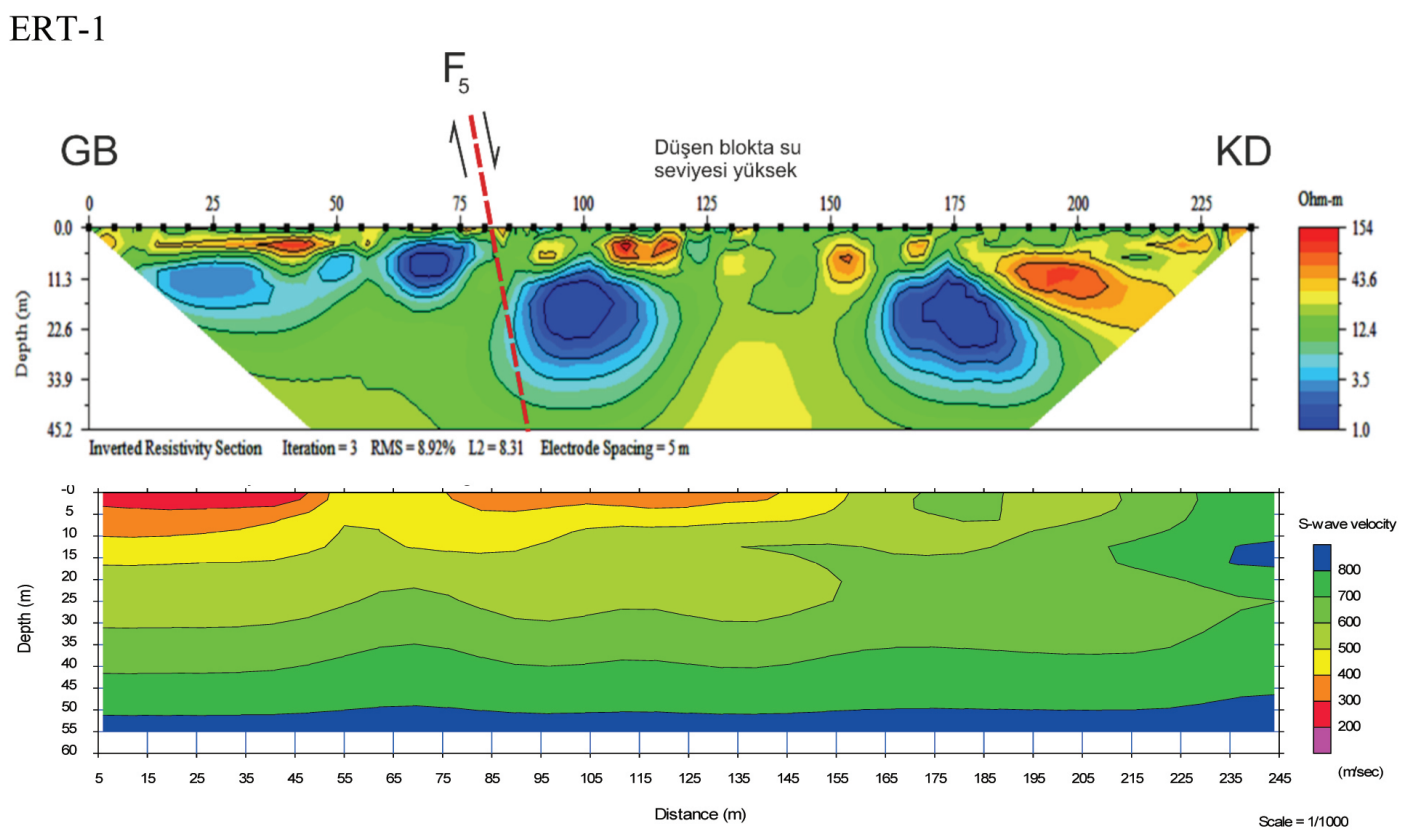

ERT-7
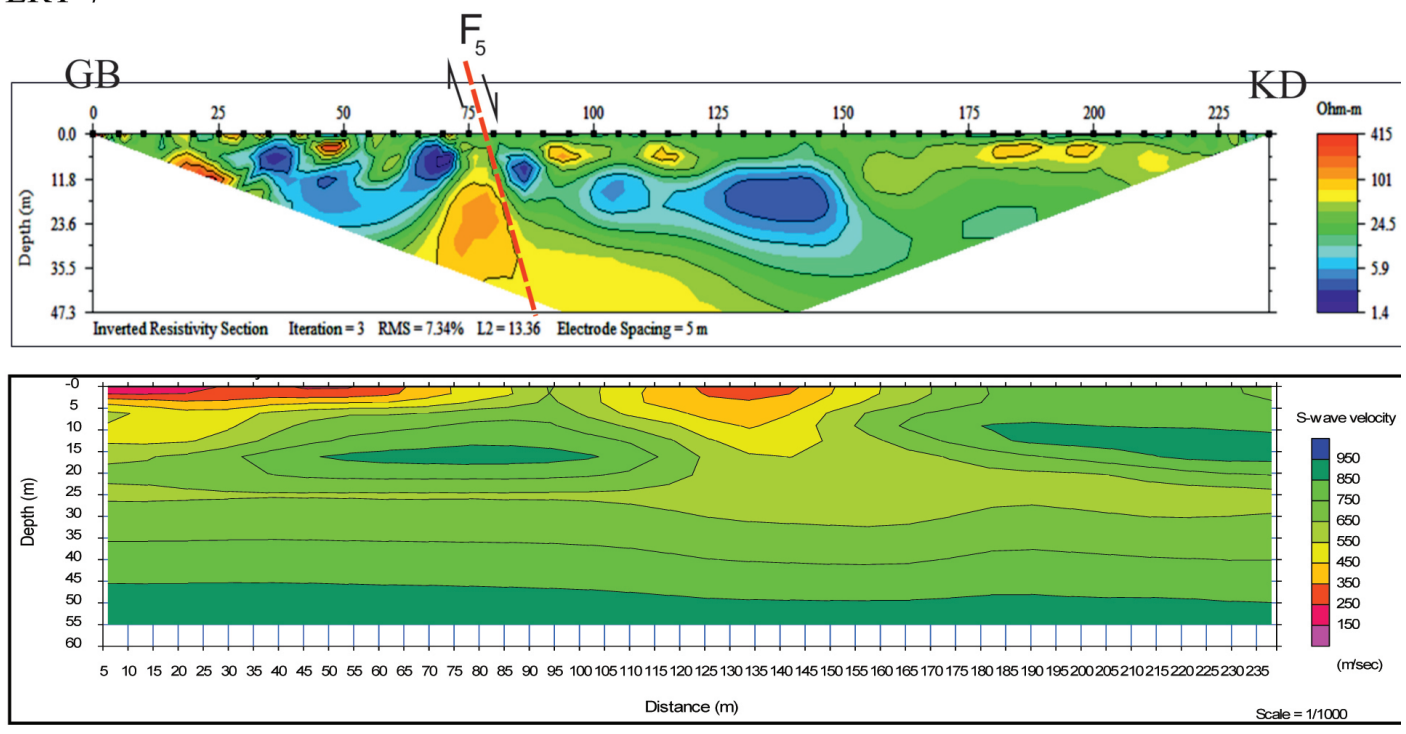

Şekil 8. $\mathrm{F}_{5}$ fayını kesen ve hendek oluşumunu gösteren ERT-1 ve ERT-7 elektrik özdirenç tomografi kesitleri.

Figure 8. The measurements lines of the electrical resistivity tomography (ERT-1 and ERT-7) showing the $F_{5}$ fault and trench formation. 
Kıncal, Kadakçı Koca, Koca

\section{Konsolidasyonsuz-drenajsız makaslama deneyleri}

Hizlı deneylerden (quick test) elde edilen makaslama deney sonuçları Çizelge 4'te sunulmuştur. Yüksek plastik $\mathrm{CH}$ türü killere ait direnç parametrelerinden içsel sürtünme açısı $\phi$ değeri $14^{\circ}-16^{\circ}$, kohezyon (c) değeri ise 10-12 $\mathrm{kPa}$ olarak elde edilmiştir (Şekil 10). Siltli killi kumda (SM) makaslama direnci parametreleri daha yüksek olarak elde edilmiştir $\left(\phi=37^{\circ}, \mathrm{c}=20\right.$ $\mathrm{kPa})$. Yüksek plastik siltler ve killi siltlerde içsel sürtünme açısı $\phi=13^{\circ}-20^{\circ}$, kohezyon değeri (c) ise $8-20 \mathrm{kPa}$ mertebesinde saptanmıştır (Çizelge 4). Çizelge 4'teki örneklere ait Coulomb yenilme zarflarının eşitlikleri aşağıda verilmiştir:

1-nolu örnek; $\mathrm{t}=10+0.29, \mathrm{r}=0.98$

2-nolu örnek; $\mathrm{t}=12+0.25, \mathrm{r}=0.98$

3-nolu örnek; $\mathrm{t}=20+0.36, \mathrm{r}=0.97$

4-nolu örnek; $\mathrm{t}=8+0.23, \mathrm{r}=0.99$

5-nolu örnek; $\mathrm{t}=20+0.75, \mathrm{r}=0.99$ (Şekil 9) (8)

\section{Konsolidasyonlu-drenajlı (CD) deneyler}

Konsolidasyonlu-drenajlı deneylerden elde edilen pik ve rezidüel makaslama dayanımı parametreleri, aglomeraların yerinde ayrışmasıyla oluşmuş, montmorillonit türü yüksek plastik (CH) killere aittir. Konsolidasyonlu-drenajlı makaslama deneylerinin sonuçları Çizelge 5 'te sunulmuştur. Doğrusal ve eğrisel ölçülere göre elde edilen yenilme zarfları düşük bir normal gerilme değerinden sonra hemen hemen çakışmaktadır (Şekil 11). Doğrusal regresyon analizleriyle hesaplanan ilgileşim katsayıları Eşitlik 1, 2 ve 5'te verilmiştir ve geometrik regresyon analizleriyle elde edilen değerlere göre (Çizelge 5) daha yüksektir.

Çizelge 4. Hızlı deneylerden (UU) elde edilen makaslama direnci parametreleri ve Atterberg limitleri deney sonuçları.

Table 4: Results of shear strength parameters obtained from the quick tests (UU) and the results of the Atterberg limits.

\begin{tabular}{|c|c|c|c|c|c|c|c|c|c|}
\hline \multirow{2}{*}{$\begin{array}{l}\text { Örnek } \\
\text { no }\end{array}$} & \multirow{2}{*}{$\begin{array}{c}\gamma n \\
\left(\mathbf{k N} / \mathbf{m}^{3}\right)\end{array}$} & \multirow{2}{*}{$\mathbf{G}$} & \multirow{2}{*}{$\begin{array}{l}\omega_{L L} \\
(\%)\end{array}$} & \multirow{2}{*}{$\begin{array}{l}\omega_{\mathrm{PL}} \\
(\%)\end{array}$} & \multirow{2}{*}{$\begin{array}{l}\omega_{\mathrm{PI}} \\
(\%)\end{array}$} & \multicolumn{2}{|c|}{$\begin{array}{c}\text { UU-drenajsız hızlı } \\
\text { deney }\end{array}$} & \multirow{2}{*}{$\begin{array}{c}q_{u} \\
(\mathbf{k P a})\end{array}$} & \multirow{2}{*}{$\begin{array}{c}\text { Zemin } \\
\text { cinsi }\end{array}$} \\
\hline & & & & & & $\phi\left({ }^{\circ}\right)$ & $\begin{array}{c}\mathrm{C}(\mathrm{kN} / \\
\left.\mathbf{m}^{2}\right)\end{array}$ & & \\
\hline 1 & 17.3 & 2.68 & 74 & 32 & 42 & 16 & 10 & 46 & $\mathrm{CH}$ \\
\hline 2 & 16.3 & 2.68 & 78 & 31 & 47 & 14 & 12 & 42 & $\mathrm{CH}$ \\
\hline 3 & 18.0 & 2.67 & 64 & 37 & 27 & 20 & 20 & 32 & $\mathrm{MH}$ \\
\hline 4 & 16.7 & 2.67 & 63 & 37 & 26 & 13 & 8 & 28 & $\mathrm{MH}$ \\
\hline 5 & 18.3 & 2.69 & - & - & - & 37 & 20 & - & $\mathrm{SM}$ \\
\hline
\end{tabular}


Çizelge 5. Konsolidasyonlu-drenajlı makaslama deneylerinin istatistiksel sonuçları.

Table 5. Statistical results of the consolidated-drained soil shear tests.

\begin{tabular}{clllll}
\hline & \multicolumn{3}{c}{$\begin{array}{c}\text { Doğrusal regresyon } \\
\tau=\mathrm{c}+\sigma_{\mathrm{n}} \operatorname{Tan} \phi\end{array}$} & \multicolumn{2}{c}{$\begin{array}{c}\text { Geometrik regresyon } \\
\tau=\mathrm{A}\left(\sigma_{\mathrm{n}}\right)^{\mathrm{B}}\end{array}$} \\
\cline { 2 - 6 } & $\phi\left(^{\circ}\right)$ & $\mathrm{c}(\mathrm{kPa})$ & $\mathrm{r}$ & Makaslama dayanımı & $\mathrm{r}$ \\
Pik & 31 & 38 & 0.95 & $\tau_{p}=8.909\left(\sigma_{\mathrm{n}}\right)^{0.5733}$ & 0.94 \\
Rezidüel & 24 & 10 & 0.92 & $\tau_{r}=0.4118\left(\sigma_{\mathrm{n}}\right)^{1.0865}$ & 0.88 \\
\hline
\end{tabular}

$\mathrm{Bu}$ nedenle makaslama dayanımının MohrCoulomb eşitliğiyle verilmesi daha uygun olacaktır. Şev duraylılığı açısından önem taşıyan rezidüel makaslama dayanımı parametreleri her

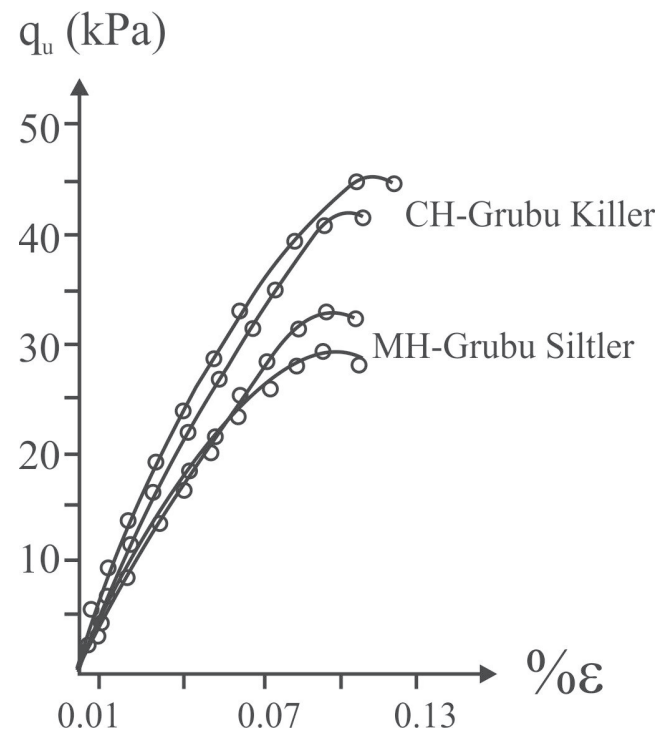

Şekil 9. Yüksek plastik zemin örneklerinin tek eksenli sıkışma dayanımı ve deformasyon eğrileri.

Figure 9. The uniaxial compressive strength and strain curves of the soil samples with high plasticity. örnek seti için doğrusal regresyon analizleriyle ayrı ayrı hesaplanmıştır. Buna göre değeri 0-10 $\mathrm{kPa}$, içsel sürtünme açısı da $24^{\circ}-31^{\circ}$ arasında değerler almıştır (Çizelge 5).

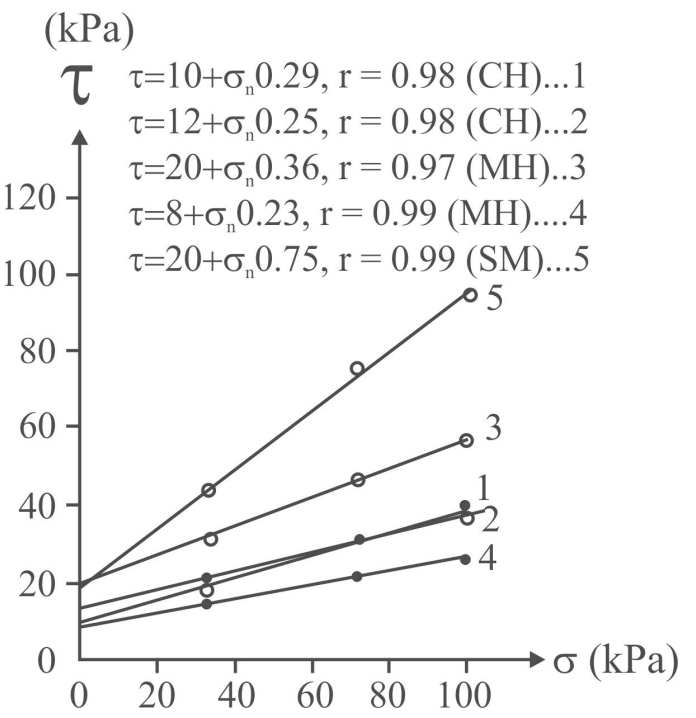

Şekil 10. Aglomera ayrışma ürünü rezidüel zeminlerin drenajsız şartlarda yenilme zarfları.

Figure 10. Failure envelopes in undrained conditions for the residual soil materials produced as a result of weathering process of the agglomerates. 
Kıncal, Kadakçı Koca, Koca

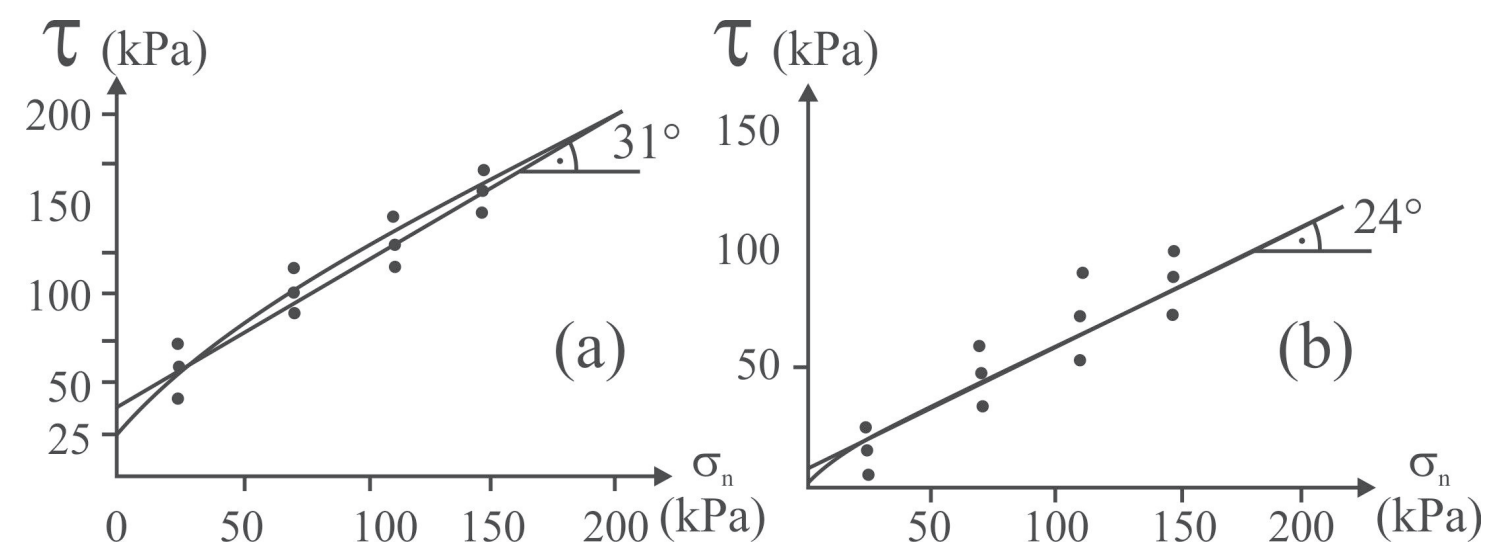

Şekil 11. Aglomera ayrışma ürünü killi zeminlerin doğrusal ve doğrusal olmayan yenilme zarfları: a) Pik değerler b) Rezidüel değerler.

Figure 11. Linear and non-linear failure envelopes of the clayey soils of weathering product of the agglomerate: a) Peak values, b) Residual values.

\section{Heyelanın kayma dairesinin yeri}

Heyelanın kayma dairesinin yeri arazi gözlemleri, sondaj karotlarının jeoteknik değerlendirmesi, jeofizik ölçümler, SK-5 ve SK-8 sondaj kuyularında gerçekleştirilen inklinometre okumaları ve SK-1, SK-4 ve SK-5 sondaj kuyularında presiyometre deney sonuçlarının değerlendirilmesi sonucu belirlenmiştir. Limit denge yöntemiyle gerçekleştirilen şev duraylılı̆̆ 1 analizlerinde olası kayma dairesinin yeri belirlenmiş ve deneysel olarak (kuyu içi ölçüm ve deneyler) bulgulanmış kayma dairesinin yeriyle karşılaştırılmıştır.

\section{Kayma dairesinin yerinde deney ve gözlemlerle belirlenmesi}

Sondaj profillerinde, yüzeyde 8-15 m kalınlığında plastik özellikte siltli killer ve kumlu-siltli killerden oluşan su içeriği yüksek/ suya doygun koşullarda bir zemin tabakası yer almaktadır. $\mathrm{Bu}$ malzemeler hareket etmiş heyelan malzemesinin \% 50'den daha fazlasinı oluşturmaktadır (predominantly fine material). $\mathrm{Bu}$ seviyenin altında yer alan aglomeralar profil boyunca iki farklı ayrışma derecesinde gözlenirler (Şekil 12). Zemin tabakasının hemen altında, oldukça (HW) - tamamen ayrışmış (CW), daha sonra bloklu yapıdaki, sert kaya özelliğini korumuş, orta derecede ayrışmış olarak (MW) yer alırlar (Şekil 12). Sondajlarda kalınlığ 1 $0.5-1.0 \mathrm{~m}$ aralığında olan ince tüf seviyesi geçildikten sonra kumtaş1-şeyl ardalanmasından oluşan Bornova Karmaşığı'na girilmiştir. 


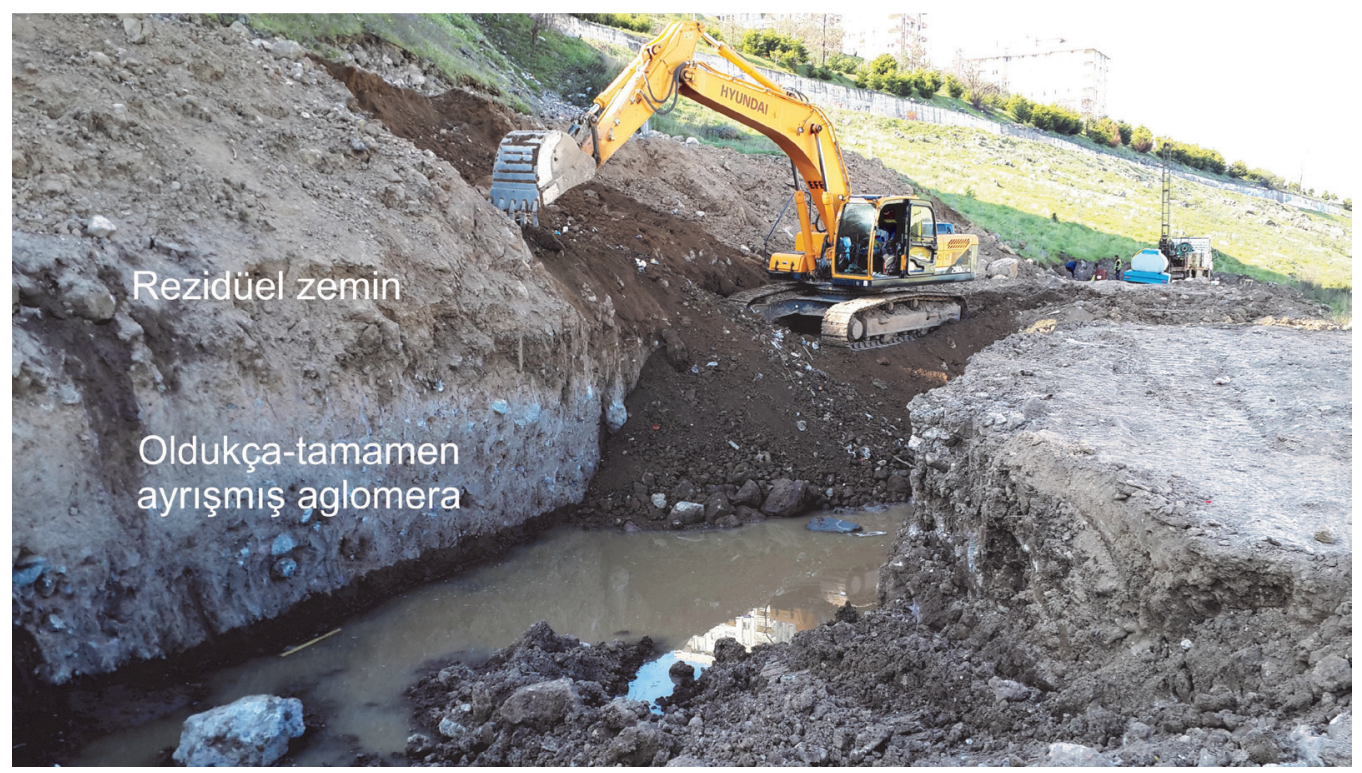

Şekil 12. Okul binasıyla $\mathrm{F}_{1}$-fayı arasında yer alan kazı şevinde açığa çıkan, zayıf kaya-sert zemin arasında yer alan ayrışmış aglomeralardaki geçiş zonu (yeraltı suyu yüzeye yakın konumda).

Figure 12. Transition zone between weak rock and hard soil outcropping at the excavation slope in the weathered agglomerates located in between school building and $F_{1}$ fault (groundwater level is near the ground surface).

Yukarıda sözü edilen istif $\mathrm{F}_{1}$ ve $\mathrm{F}_{5}$ fayları arasında yer alan hendekte/cepte açılan sondajlarda (SK-1, SK-2, SK-3, SK-4 ve SK6) gözlenmiştir. Orta derecede ayrışmış, sert ve bloklu yapıdaki aglomeralara SK-1, SK-2 ve SK-3 nolu sondajlarda 27 - 31 m'de, SK-4 sondajında 28-32 m'de (SK-4 sondaj1 $\mathrm{F}_{2}$ ters fayını kesmiştir) ve SK-6'da ise yüzeye daha yakın konumda, 21-24 m arasında girilmiştir. Hendek dışında açılan sondajlardan SK-7'de 20.5 m'de (SK-7 sondajı $F_{3}$ fayını kesmiştir, Şekil 13), SK-8'de 24.5 m'de, SK-9'da 12. m'de, SK-10'da 15.5 m'de Bornova Karmaşı̆̆g'na girilmiştir.

SK-1, SK-4 ve SK-5 kuyularında presiyometre deneyleri yapılmıştır. SK-1'de 10 . metredeki deneyde en düşük net limit basınç $\mathrm{P}_{\mathrm{L}}=1.25 \mathrm{~kg} / \mathrm{cm}^{2}(122.5 \mathrm{kPa})$, SK-4'te $12.5 \mathrm{~m}$. derinlikte net limit basınç $P_{L}=1.74 \mathrm{~kg} / \mathrm{cm}^{2}(170.6$ $\mathrm{kPa}), 13.5 \mathrm{~m}^{\prime}$ de ise $2.05 \mathrm{~kg} / \mathrm{cm}^{2}(201.0 \mathrm{kPa})$, SK-5'te 12.0 m'de yamaç molozu - aglomera kontağında $\mathrm{P}_{\mathrm{L}}=2.23 \mathrm{~kg} / \mathrm{cm}^{2}(218.7 \mathrm{kPa})$ olarak ölçülmüştür. Presiyometre deneylerinin yapıldığ 1 sondajlarda ölçülen en düşük net limit basınç değerleri $122.6 \mathrm{kPa}<\mathrm{PL}<218.7 \mathrm{kPa}$ arasındadır. $\mathrm{Bu}$ değerlere göre sondajlarda kesilen killer "yumuşak-orta katı" kıvamdadır. Briund (1992)'e göre yumuşak killerin drenajsız kayma dayanımı Eşitlik 9 gereğince hesaplanmıştır. Killerin drenajsız kayma dayanımı:

$$
\left(\mathrm{c}_{\mathrm{u}}\right)=0.67 *\left(\mathrm{P}_{\mathrm{L}}\right)^{0.75}
$$

$25<\mathrm{c}_{\mathrm{u}}<38.7 \mathrm{kPa}$ aralığında bulunmuştur. Elastisite modülü değerleri ise $10.18 \mathrm{~kg} / \mathrm{cm}^{2}$ $(998.5 \mathrm{kPa})-22.86 \mathrm{~kg} / \mathrm{cm}^{2}(2242.1 \mathrm{kPa})$ arasında değişmektedir. 


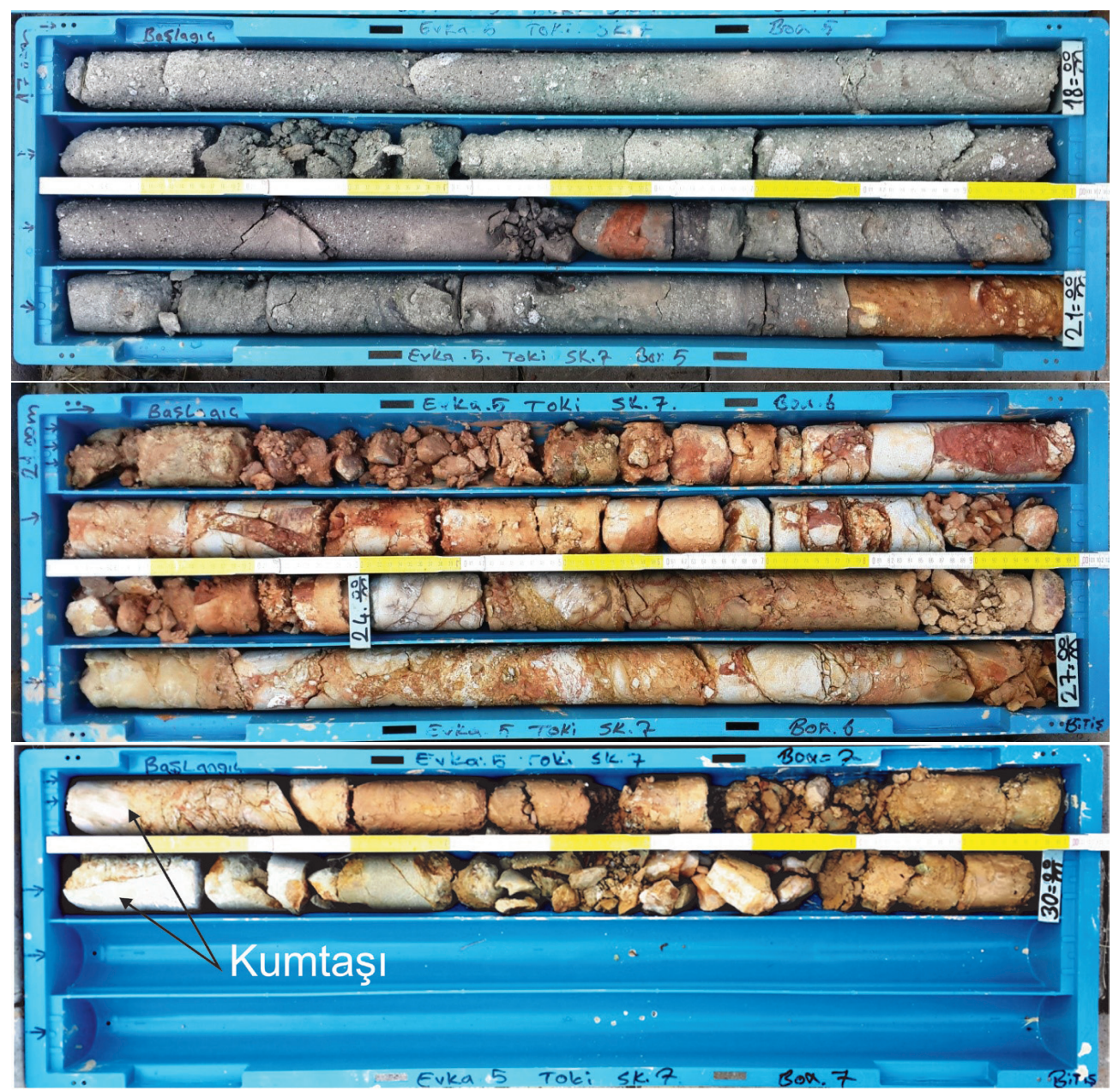

Şekil 13. SK-7 sondaj kuyusunda, $21 \mathrm{~m}$ derinliğinde aglomera-filiş dokanağında gelişmiş oksitlenme-pişme nedeniyle meydana gelen pembe renkli breşik zon ( $\mathrm{F}_{3}$ fay zonu, 20.8 - 21.0 $\mathrm{m}$ arası fay kili ve 21.1 - 21.55 $\mathrm{m}$ arası da fay breşi olarak değerlendirilmiştir). Figure 13. In BH-7 borehole, down to $21 \mathrm{~m}$ from the ground surface, breccia zone with pink colour occurred due to oxidation and baking in the contact between agglomerate and flysch units.

Yukarıda verilen bu değerler kuyularda en düşük net limit basınçların elde edildiği seviyelerin üzerinde $2.80 \mathrm{~kg} / \mathrm{cm}^{2} \leq \mathrm{P}_{\mathrm{L}} \leq 3.13$ $\mathrm{kg} / \mathrm{cm}^{2}$, altındaki basınç değerleri ise $2.68 \leq \mathrm{P}_{\mathrm{L}}$ $\leq 15.43 \mathrm{~kg} / \mathrm{cm}^{2 \prime}$ ye kadar değişen aralıklarda değerler almaktadır.

SK-5 ve SK-8 kuyularında inklinometre okumaları yapılmıştır. SK-5'te ilk okumada (21.05.2015) $9.5 \mathrm{~mm}$, ikinci okumada (26.05.2015) $12 \mathrm{~mm}$ kayma yönünde yer değiştirme tespit edilmiştir. Kayma dairesinin derinliği $12 \mathrm{~m}$ olarak belirlenmiştir (Şekil 14). SK-8'de ilk okumada $18.5 \mathrm{~mm}$, ikincide ise 20.5 mm mertebesinde yanal yönde yer değiştirme okunmuştur (Şekil 15). SK-8'de hareketin yönü, heyelanın hareket yönünde değil (K55B), $\mathrm{F}_{5}$ fayına doğrudur. Kayma dairesi SK-5 ve SK-8'de yaklaşık aynı derinlikten $(12 \mathrm{~m})$ geçmektedir. $\mathrm{Bu}$ durum, hareketin yüzeyde yer alan ve kalınlığ 1 8-15 m. arasında değişen yamaç molozu + aglomera ayrışma ürünü plastik killer/killi siltler içinde olduğuna işaret etmektedir. 
Saha : EVKA 5 Kuyu : SK-5

Kümülatif deplasman aşağıdan

Referans Ölçümü : 21/05/2015 DOĞU Deplasman [mm]

KUZEY Deplasman [mm]

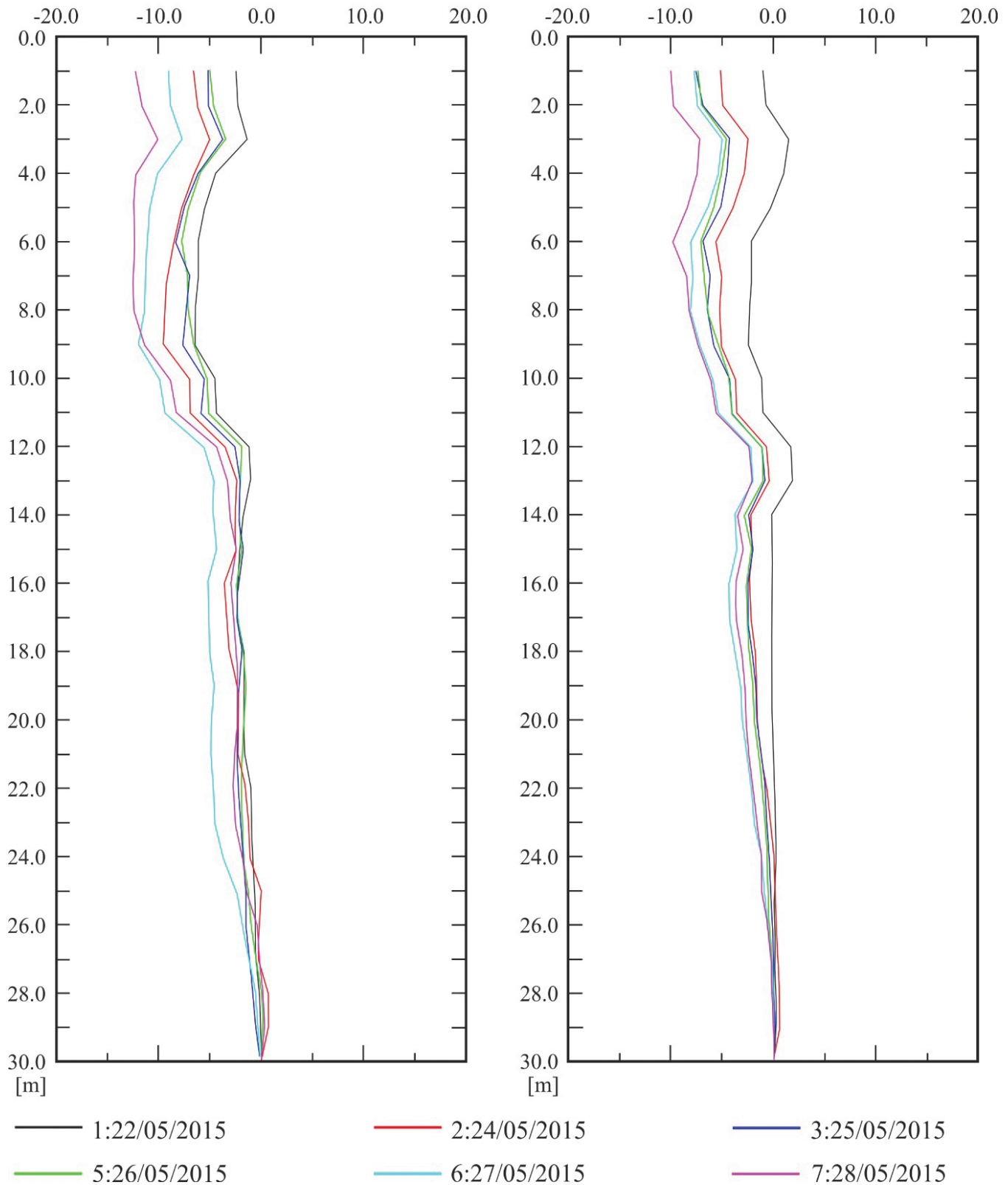

Şekil 14. SK-5 sondaj kuyusundan alınmış inklinometre okumalarının sonuçları.

Figure 14. The results of inclinometer readings taken from the borehole-5. 
Kıncal, Kadakçı Koca, Koca

Saha: EVKA5 Kuyu: SK8

Kümülatif deplasman Aşağıdan

Referans ölçümü 000:21/05/2015

DOĞU Deplasman [mm]

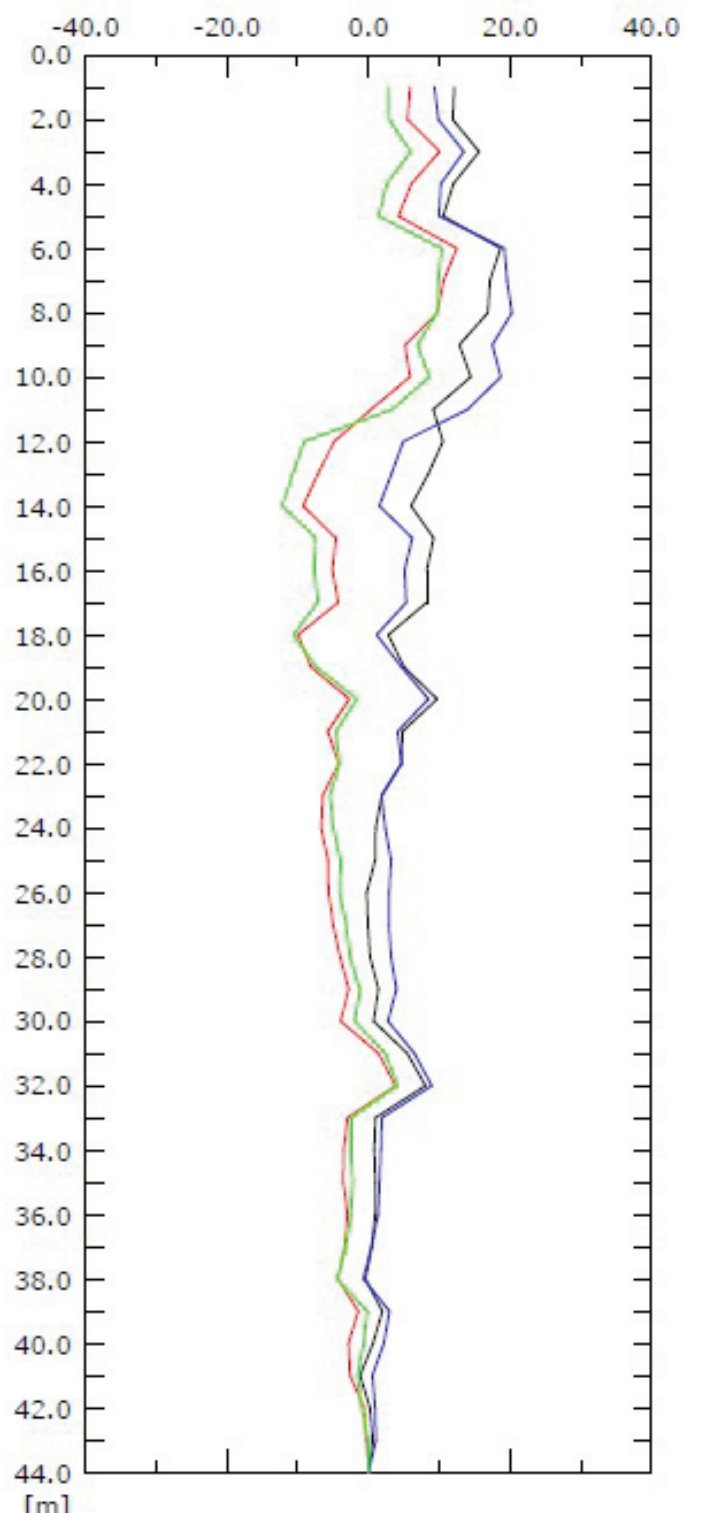

[m]

$001: 22 / 05 / 2015$

$004: 26 / 05 / 2015$
KUZEY Deplasman [mm]
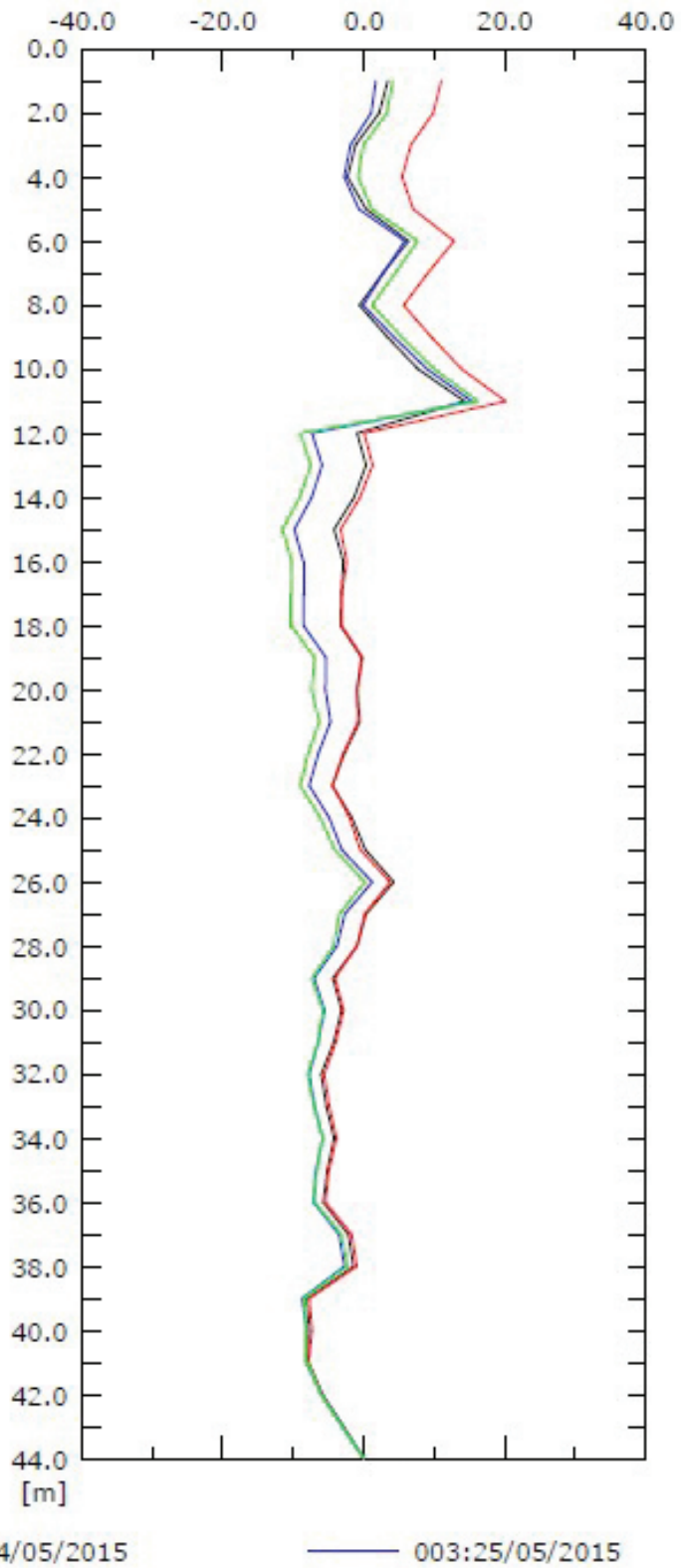

$002: 24 / 05 / 2015$

$003: 25 / 05 / 2015$

Şekil 15. SK-8 sondaj kuyusundan alınmış inklinometre okumalarının sonuçları.

Figure 15. The results of inclinometer readings taken from the borehole-8. 


\section{Kayma dairesi yerinin şev duraylılığı çalışmalarıyla belirlenmesi}

Heyelan sahası için Bishop Limit Denge Yöntemi kullanılarak şev duraylılığ 1 araştırmaları yapılmıştır (Şekil 16). Burada amaç kayma dairesinin yerinin kestirilmesi ve diğer yöntemlerden yararlanılarak elde edilen kayma dairesinin yeriyle karşıllaştırılmasıdır. Şev stabilite analizlerinde $\mathrm{CH}-\mathrm{MH}$ tipi yüksek plastik killer ve killi siltler için konsolidasyonlu-drenajlı makaslama direnci parametreleri kullanılmıştır. Diğer tüm jeolojik birimlerin direnç parametreleri Çizelge 6'da toplu olarak verilmiştir.
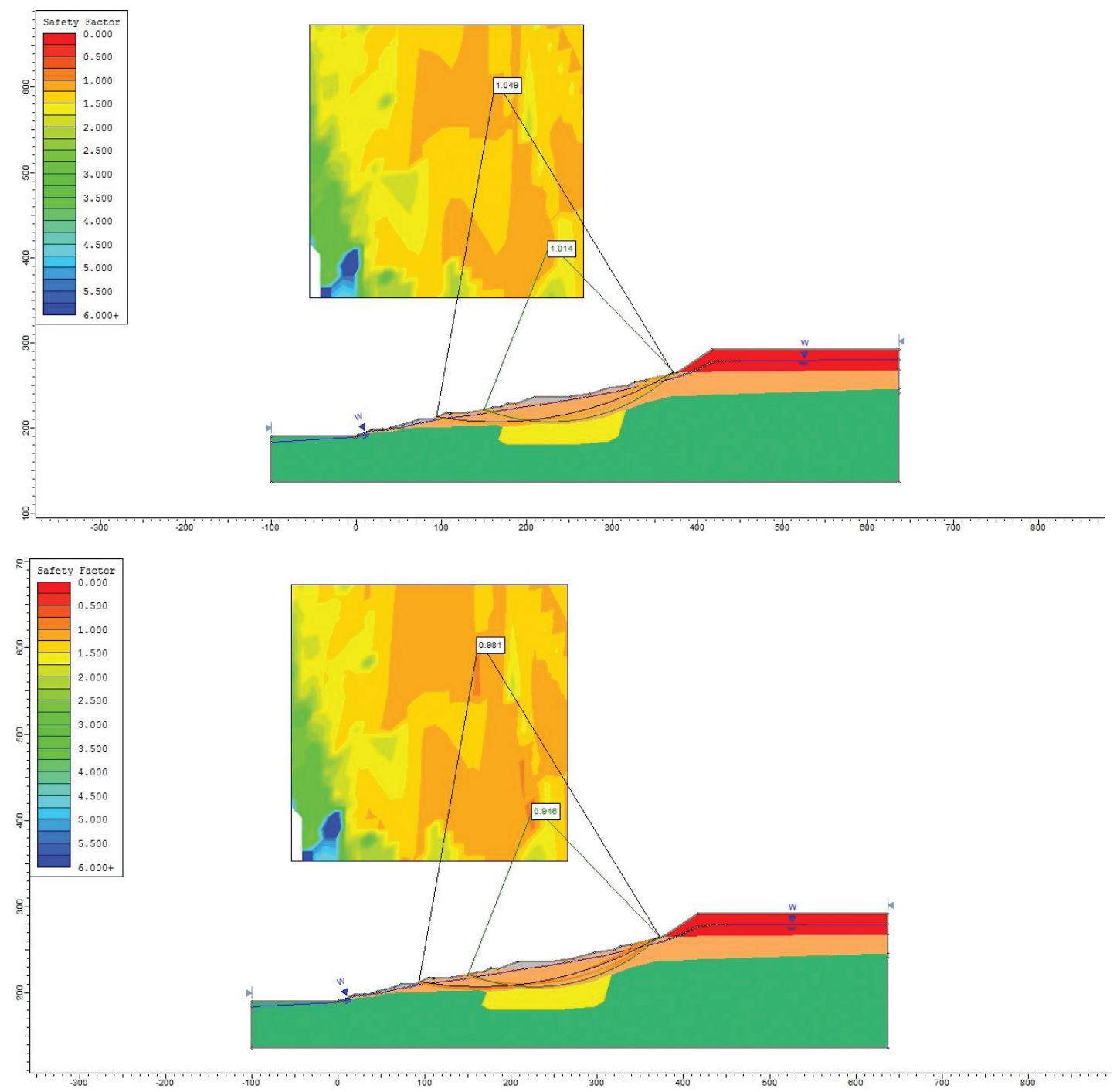

Şekil 16. Basitleştirilmiş Bishop yöntemiyle gerçekleştirilen şev stabilite analizlerinden elde edilen kayma daireleri ve FoS değerleri.

Figure 16. Slip circles acquired from the slope stability analyses performed using the simplified Bishop's method and the values of FoS. 
Kıncal, Kadakçı Koca, Koca

Çizelge 6. Şev stabilite analizlerinde kullanılan jeolojik birimlerin birim ağılık ve makaslama dayanımı parametresi değerleri. Table 6: Unit weight and shear strength values of the geological units used in the slope stability analyses.

\begin{tabular}{|c|c|c|c|c|}
\hline Birim & $\begin{array}{c}\text { Birim ağırlık } \\
\left(\mathbf{k N} / \mathrm{m}^{3}\right)\end{array}$ & c (kPa) & $\phi\left({ }^{\circ}\right)$ & FoS \\
\hline Yamaç molozu & 16.85 & 3.0 & 21 & \\
\hline $\begin{array}{l}\text { Rezidüel zemin } \\
(\mathrm{CH} / \mathrm{MH})\end{array}$ & 16.65 & 8.0 & 12 & \\
\hline $\begin{array}{l}\text { Andezit(soğuma yüzeyi), } \\
\text { Koca ve Kıncal (2004) }\end{array}$ & 23.05 & 260 & 16 & $0.946-0.981$ \\
\hline $\begin{array}{l}\text { MW-HW aglomera-matriks (zayıf kaya), } \\
\text { Koca (1995) }\end{array}$ & 20.60 & 40 & 33 & \\
\hline $\begin{array}{l}\text { Kumtaşı (filiş), } \\
\text { Köse (2007) }\end{array}$ & 23.05 & 250 & 38 & \\
\hline
\end{tabular}

Aglomera ayrışma ürünü yüksek plastik killerin/siltlerin makaslama dayanımı parametrelerinden $\phi=13^{\circ}$ alındı ğında (diğer parametreler aynı kalmak üzere) $\mathrm{FoS}=1.014^{\prime} \mathrm{e}$ çıkmaktadır (Şekil 16a). $\phi=16^{\circ}$ için ise $\mathrm{FoS}=$ 1.019'a çıkmaktadır. İncelenen heyelanın duraylılığ1 içsel sürtünme açısından çok kohezyon değerine duyarlıdır. Analizlerden elde edilen kayma dairesinin yeri inklinometre sonuçlarından ve sondaj karot tanımlamalarından elde edilen derinliklerle örtüşmektedir. Kayma dairesi başlangıçta (güneydoğudan itibaren) aglomera ayrışma ürünü plastik kil/silt içerikli rezidüel zemin katmanının altından, daha sonra aglomera-fliş dokanağından ilerlemekte ve $\mathrm{F}_{4}$ fayının çok yakınından geçmektedir (Şekil 16). Kayma zonunun güncel topoğrafyayı kestiği yer; $\mathrm{F}_{4}$ fayının 30 - $35 \mathrm{~m}$ güneybatısında, yaklaşık 190 m kotunda yer almaktadir. Burada kayma zonu yüzeylenmiştir (Şekil 17). Ancak geniş bir makaslama zonu şeklinde belirgin hale gelmiş bir görüntü henüz bu noktada oluşmamıştır. $\mathrm{Bu}$ durum heyelanın henüz progresif bir aşamaya geçmediğine işaret etmektedir. Heyelanın esas kayma dairesi, yüzeye yakın konumda, en derin noktası $15 \mathrm{~m}$ kadar olan (İlkokul binasının kuzey cephesi) ve $\mathrm{F}_{1}$ ile $\mathrm{F}_{4}$ fayları arasından geçen yay şekilli yüzeydir (Şekil 16). Kayma yüzeyi üzerinden bu malzemeler kuzeybatıya doğru (K 55 B yönünde) hareket etmektedir.

İlkokulu da içine alan heyelanlı sahanın kayma ve çökme bölgeleri, jeolojik bir hendek ve/veya faya yaslanmış bir cep üzerinde yer almaktadır. Bu cep $F_{5}$ ve $F_{1}$ faylarının fay önü düzlüklerinde yer alır (Şekil 18). $F_{2}$ fayının ise fay düzleminin gerisinde, güneydoğuda yer alır. $\mathrm{F}_{5}, \mathrm{~F}_{1}$ ve $\mathrm{F}_{2}$ faylarıyla denetlenmiş çöküntü alanı su birikimi için uygun bir alandır.

$\mathrm{Bu}$ nedenle fay cebi içinde yeraltı suları birikmektedir. $\mathrm{F}_{5}$ fayını GB-KD yönünde kesen ve yarı basınçlı akifer oluşumunu gösteren şematik kesit Şekil 18'de verilmiştir. 

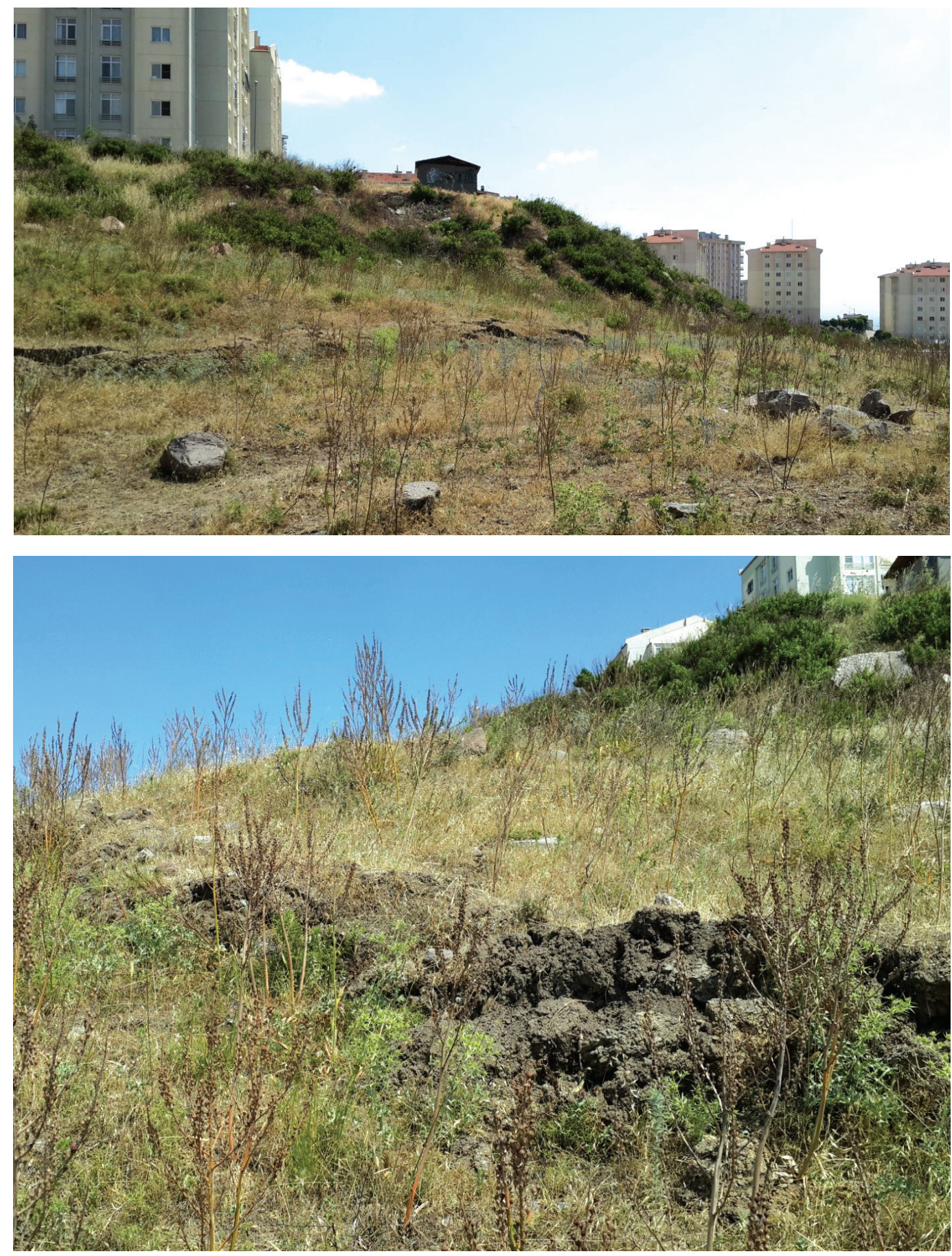

Şekil 17. Heyelanın topuk bölgesinde meydana gelen deformasyonlar (kuzeybatıdan güneydoğuya doğru fotoğraf çekimi yapılmıştr).

Figure 17. Deformations occurred in the toe of the landslide (photograph was taken from NW towards SE-direction). 
Kıncal, Kadakçı Koca, Koca

$\mathrm{Bu}$ cebin en altında az geçirimli filiş, en üstünde aglomeraların yerinde ayrışmasıyla oluşmuş 10-15 m kalınlığında plastik killerden ve kumlu, killi siltlerden oluşmuş heyelan malzemesi yer almaktadır. Aglomera yı̆̆ışım bantlarının eğim yönleri nedeniyle su akım yönü $F_{5}$ fayına doğrudur (Şekil 18). Üç tarafı geçirimsiz ve/veya az geçirimli malzemelerle kaplı fay cebi su gelişiyle (aşırı beslenmeyle) yarı basınçlı bir akifere dönüşmüştür. Cep üzerinde açılan SK-1, SK-2 ve SK-4 sondaj kuyularında yeraltı suyunun artezyen yaptığ gözlenmiştir. $\mathrm{F}_{2}$ fay engeli nedeniyle akiferin $\mathrm{KD}$ cephesi kısmen açıktır. Ancak hidrolik eğim $\mathrm{F}_{5}$ fayına doğru (batıya doğru) olduğundan su havza dışına kaçamamaktadır (Şekil 19). edilen kohezyon değerlerinden $\left(8 \leq \mathrm{c}^{\prime} \leq 20 \mathrm{kPa}\right)$ ise daha yüksek olduğu belirlenmiştir. Ancak elde edilen tüm kohezyon değerlerinin birbirine oldukça yakın değerlerde oldukları görülmüştür.

$F_{1}$ ve $F_{5}$ fayları sirasiyla kuzeybatiya ve kuzeydoğuya eğimli faylardır ve birbirlerini keserek bir kama oluşturmaktadırlar. Kamanın ara kesitinin konumu K 18 D/65 KD'dur. İlginç bir şekilde, meydana gelen heyelan hareketi fay düzlemlerinin oluşturduğu ara kesit boyunca değil, $F_{5}$ fayının doğrultusuna yakın bir konumda gelişmiştir. Kesişen iki fay düzleminin ara kesitinin dalım yönü şev dışına değil, şev tabanına doğru olduğundan kama tipi kayma olasılığ 1 yoktur. Bu durum, kaymanın derin bir kayma olmayıp, yüzeyde mevcut fayları da kesen

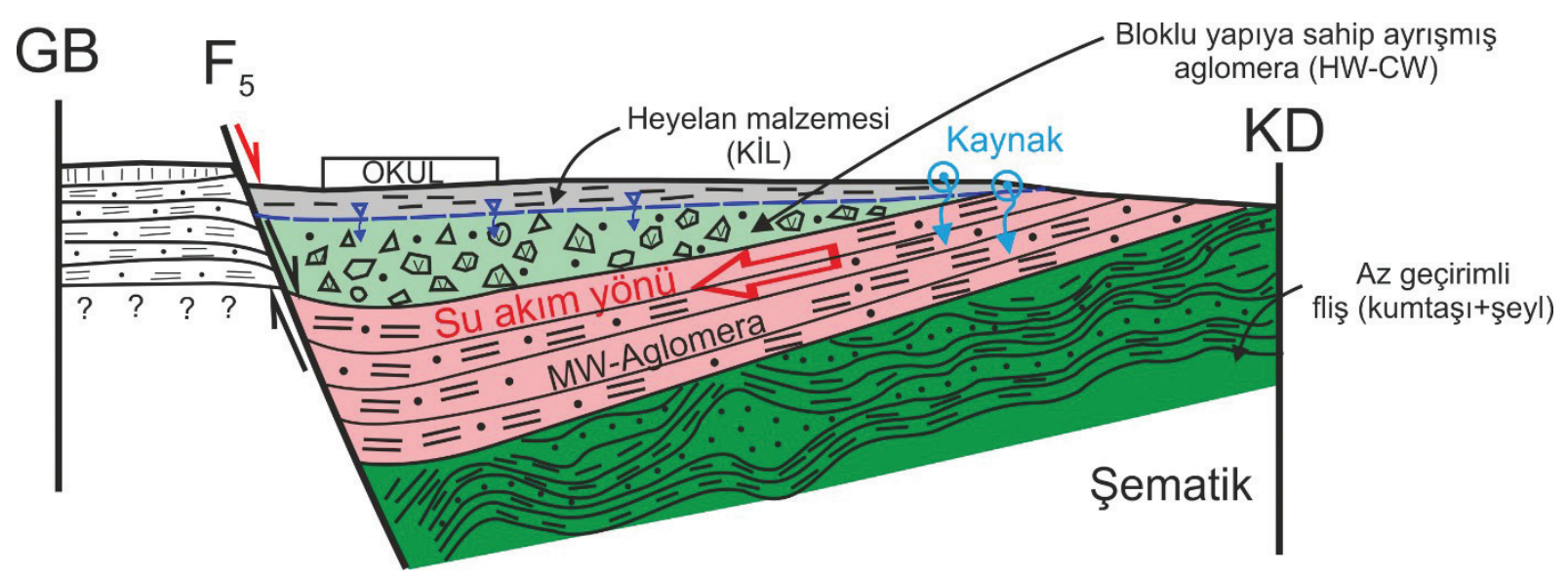

Şekil 18. $\mathrm{F}_{5}$ fayının düşen bloğu üzerinde fay hareketi nedeniyle oluşmuş fay cebi ve yarı basınçlı akifer oluşumu.

Figure 18. Fault pocket formed at the hanging wall of $F_{5}$ fault due to the faulting mechanism and the formation of confined aquifer.

\section{DEĞERLENDİRME}

Presiyometre net limit basınçları yardımıyla killerin drenajsız kayma dayanımı değerleri $25 \leq \mathrm{c}_{\mathrm{u}} \leq 38.7 \mathrm{kPa}$ olarak elde edilmiştir. $\mathrm{Bu}$ değerlerin konsolidasyonlu-drenajlı makaslama deneylerinden elde edilen kohezyon değerleriyle (10-38 kPa) örtüştüğü, hızlı deneylerden elde (faylar kayma düzlemi tarafından kesildikleri için bu düzlemin içinde kalmışlardır ve hareketin yönünde eğim kazanmışlar, tilt olmuşlardır) bir kayma dairesinin olduğuna işaret etmektedir. Bir diğer anlatımla, $F_{5}$ fayı, $F_{1}$ fayının eğim yönünde hareket eden kütlenin yan duvarı olarak çalışmıştır. 
Gerek limit denge analizlerinin sonuçları gerekse de karot determinasyonları ve inklinometre ölçümlerinin sonuçları kayma dairesinin hendekte 12-15 m, $\mathrm{F}_{2}$ fayından sonra yüzeye daha yakın konumda olacak şekilde 8-10 m derinlikten geçtiğini göstermiştir. $F_{2}$ fay1 heyelan hareketinin önünde, derin kayma hareketini önleyici bir jeolojik bariyer görevi yapmaktadır. Bu durumda $\mathrm{F}_{1}$ fayından itibaren ve $\mathrm{F}_{5}$ fayının doğrultusu boyunca büyük bir kütlenin kuzeybatıya doğru hareket etme olasılığ $\mathrm{F}_{2}$ fay1 tarafından engellenmiştir. Bir diğer anlatımla,
$\mathrm{F}_{2}$ ters fayı sahada oluşabilecek derin kaymayı durdurmuştur. Olası bir derin kaymayı engellediği için $F_{2}$ fayı pozitif bir etkiye sahiptir. $F_{2}$ fayının jeolojik bariyer rolü olmasaydı, kayma dairesi olasilikla SK-1, SK-2 ve SK-4 sondajlarında sirasiyla $28 \mathrm{~m}, 30 \mathrm{~m}$ ve 32 m'den, SK-7, SK-9 ve SK-10 sondajlarında ise aglomera-Bornova Karmaşı ğ 1 kontağından olmak üzere sirasıyla 21 m, 17 m ve 15.5 m'den geçeceği düşünülmektedir (Şekil 19). Yukarıda verilen olası kayma zonu karotların jeoteknik loglanması sırasında yapılan gözlemlerden belirlenmiştir.

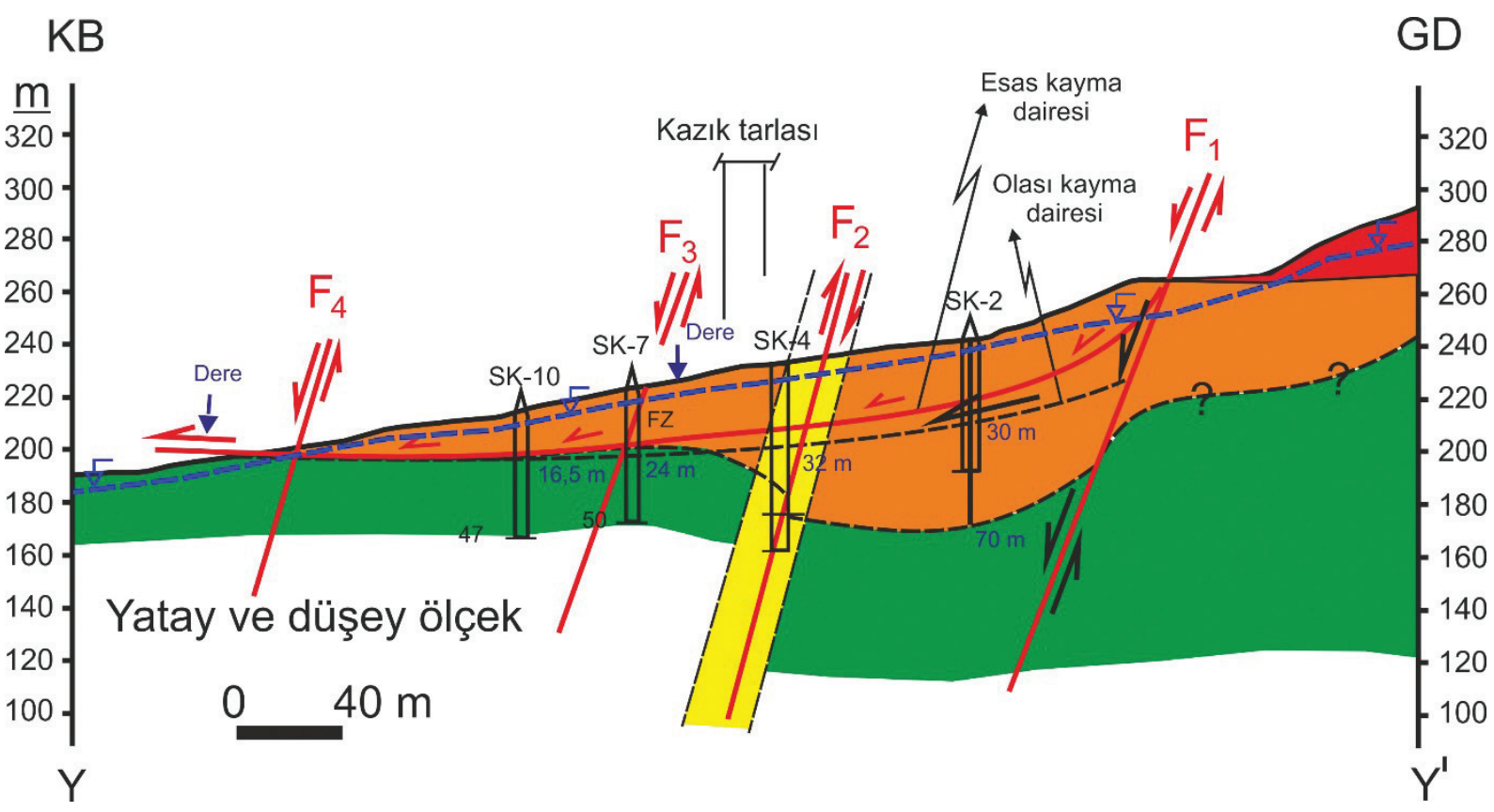

Şekil 19. $\mathrm{F}_{2}$ ters fayının olmaması durumunda gelişecek olası derin kaymanın sınırları ve heyelanı önleyici bir çözüm olarak önerilen kazik grubunun konumu.

Figure 19. In the case of the absence of $F_{2}$ fault, the location of possible deep slip surface and the location of pile group proposed in order to prevent the landslide. 
Kıncal, Kadakçı Koca, Koca

Yukarıda verilen derinliklerde aglomeraların ayrışma dereceleri, direnç özellikleri değişmektedir. $\mathrm{Bu}$ derinliklerin altında aglomeralar sert kaya özelliğini koruyan bir yapıda bulunmaktadır. Aglomeralar bu derinliklerden itibaren yüzeye doğru ilerleyen profil boyunca, az ayrışmış kayadan zemine dönüşen bir ayrışma profili sunarlar. Yüzeye yakın kesimlerde $(\mathrm{d}<15 \mathrm{~m})$ makaslama dalga hızları $150 \leq \mathrm{V}_{\mathrm{s}} \leq 500 \mathrm{~m} / \mathrm{s}$ arasında değerler almıştır.

$\mathrm{Bu}$ araştırma başlatılmadan önce (1. etap çalışmaları), $F_{1}$ fayının fay önü düzlüğünde, ilkokul binasının $22 \mathrm{~m}$ GD'da, KD-GB yönelimli, $185 \mathrm{~m}$ uzunluğunda ve $12 \mathrm{~m}$ derinliğinde kazıklı istinat duvarı imalatı gerçekleştirilmiştir. Projenin uygulama aşamasında yapılan derin kazıda aglomeralardaki ayrışma durumu ve profil boyunca su içeriğindeki değişim yerinde gözlenmiştir (Şekil 12). F fayı boyunca kayan malzeme temizlendikten sonra açılan kazı şevinde (kazıklı istinat duvarı imalatı işlemi) açığa çıkan aglomeralarda sert zemin-zayıf kaya geçişi izlenebilmiştir (Şekil 12). Aglomera ayrışma ürünü, orta katı-yumuşak kıvamdaki plastik kil ve siltler heyelan sahasındaki zemin profilinin en üstünde yer alır. İlkokul binasını da içine alan hendekte bu seviyenin kalınlığ 12 $15 \mathrm{~m}$ arasındadır. Bu zemin seviyesinin altında aglomeralar oldukça-tamamen ayrışmış $(600 \leq$ $\mathrm{V}_{\mathrm{s}} \leq 700 \mathrm{~m} / \mathrm{s}$ ) zayıf kaya (15-28m) özelliğindedir ve daha sonra göreceli sert/sağlam kaya özelliği göstermektedir $\left(700 \leq \mathrm{V}_{\mathrm{s}} \leq 950 \mathrm{~m} / \mathrm{s}\right)$. Sağlam kaya özelliğindeki aglomeralar, $60 \mathrm{~m}$ derinliğe kadar hendek içinde devam etmekte ve daha sonra Bornova Karmaşı̆̆g'na girmektedir (Şekil 19). Karmaşıkta MASW ölçümlerden elde edilen makaslama dalga hızları $\mathrm{V}_{\mathrm{s}}>1300 \mathrm{~m} / \mathrm{s}$ mertebesindedir.

Hendek dışında ( $\mathrm{F}_{2}$ fayının kuzeydoğusunda) sağlam kaya özelliğindeki aglomeralara hiçbir sondajda rastlanmamıştır. $\mathrm{Bu}$ sondajlarda aglomeralar ya zemin özelliğinde ya da oldukçatamamen ayrışmış, örselenmiş kaya malzemesi özelliğindedir. $\mathrm{Bu}$ nedenle sondajlarda zeminkaya-zemin olarak tekrarlanan seviyeler geçilmiştir. Aglomeralarda, tüf matriksin ayrışma potansiyeli bloklara nazaran daha yüksektir. Bu nedenle, tüf seviyeleri genellikle kile dönüşmüş durumdadır. Bloklar ise göreceli taş olma özelliğini korumaktadır. $\mathrm{F}_{2}-\mathrm{F}_{3}$ fayları arasında Bornova Karmaşığı'na ait kayaçlar, genelde kumtaşı baskın bir litoloji göstermeleri nedeniyle sağlam kaya özelliğindedir. $\mathrm{F}_{4}$ fayının yer aldığ 1 kesimde bu litoloji yüzeylemektedir. Buna ek olarak, kayma dairesi de bu noktada 1şıklanmaktadır (Şekil 17). Bu nokta henüz geniş bir makaslama zonu şeklini almış değildir ve kayma yönünde 44 cm'lik bir ötelenmenin meydana geldiği (Y-Y' kesiti, Şekil 19) daha sınırlı bir kayma zonu özelliği taşımaktadır. Tüm bu gözlem ve verilerin 1şığında, heyelan hareketi sı ̆̆ derinlikte, aglomeraların yerinde ayrışmasının ürünü olan rezidüel zemin özelliğindeki plastik kil ve siltlerden oluşan malzemelerle, bu seviyenin altında yer alan zayıf kaya özelliğindeki aglomeralar arasındaki zayıflık zonunda başlamıştır. Hareketin bu zonda başlamasının nedeni; heyelan başlangıcındaki yüksek topoğrafik eğim $\left(\alpha \cong 30^{\circ}\right), \mathrm{F}_{1}$ fayının gerisinde yer alan ve fay gerisinde yaklaşı $100 \mathrm{~m}$ genişliğe erişen düzlüğün (çatlaklı yapıdaki andezitlerin yer aldığı arazi kesimi, şev üst yüzeyi) heyelan sahasının beslenme alanı (bath area) olma özelliğini göstermesi, hendek oluşumu nedeniyle heyelan sahasında yarı basınçlı bir akiferin gelişmesi ve buna bağlı olarak gelişen yüksek su basınçlarının kayma eğilimini arttırması olarak gösterilebilir. Şekil 16'da görüldüğü gibi kayma dairesi aglomera-Bornova Karmaşığı kayaları arasından geçen dokanağ1 takip etmektedir. Heyelan sı ̆ 
derinlikte, moloz akması şeklinde gelişmiş bir kütle hareketi özelliği göstermektedir (Şekil 17).

2. etap jeoteknik çalışmaların sonucu olarak, yeni yağış dönemine kalmamak üzere, heyelan hareketinin durdurulmasına yönelik çalışmaların başlatılması zorunluluğu ortaya çıkmıştır. Harekete geçmiş bir kütlenin durdurulmasına yönelik başlangıç tedbirleri; heyelan sahasında yer alan binalarda su tüketiminin sınırlandırılması ve atık su isale hatlarının elden geçirilmesi olmuştur. Kayma hareketinin kalıcı olarak durdurulmasına yönelik öncelikli tedbirlerin başında da kazık imalatı gelmektedir. Kazık yerleri ve derinlikleri en ekonomik ve en güvenli olacak şekilde belirlenmiştir. Bunun için $\mathrm{F}_{2}$ ve $\mathrm{F}_{3}$ faylarının arasında yer alan bölge en uygun alan olarak seçilmiştir. Bornova Karmaşığı'nın hem yüzeye daha yakın olması hem de bu bölgedeki kumtaşlarının baskın litolojiyi oluşturması bu seçimde etken olmuştur. Kazıkların şaşırtmalı düzende ve iki sıra (kademe) olarak kumtaşlarına soketlenmesi (bağlanması) planlanmıştır. Boylarının 1/3'ü oranında bir derinlikte, kazıkların sağlam kayaya bağlanması önerilmiştir. Heyelan hareketine dik yönde (KD-GB yönünde), birinci kademe kazıklar (üst bölüm) $45 \mathrm{~m}$ derinlikte ve 174 adet ve ikinci kademe kazıklar (alt bölüm) $26 \mathrm{~m}$ derinlikte 82 adettir. Teşkil edilen kazık grubunun yeri Şekil 19 'daki kesit üzerinde gösterilmiştir. Kazık grubu hareketi önleyici bir bariyer görevi görmektedir. Buna ek olarak, gömülü dere yatakları boyunca, yeterli genişlikte hazırlanan beton kutularla (boxculvert) yeraltı ve yüzey sularının drenajının yeterlilikle sağlanması önerilmiştir. Böylece heyelan nedeniyle yüzey dolgularında meydana gelen hareketler önemli ölçüde sınırlandırılmış olacaktır. 50 noktada ve daha uzun zaman aralıklarında, periyodik olarak deformasyon ölçümlerinin alınmasına devam edilmektedir. Hareketin tamamen durdurulması, yoğun yağışlı dönemlerde fay cebinde biriken suların açılacak kuyu veya kuyularla heyelan sahasının dışına tahliyesiyle sağlanabileceğgi öngörülmektedir. $\mathrm{Bu}$ tür yüksek yamaç açısında, eğimli ve özel jeolojik koşullara sahip sahalarda su drenajının gerçekleştirilmesi adeta bir zorunluluk olarak ortaya çıkmaktadır.

$\mathrm{F}_{2}$ ters fayına bağlı blok hareketi nedeniyle Bornova Karmaşı̆̆ı'nın heyelan hareketine karş1 yönde yükselmesi, bir bariyer oluşturmas1, kazık derinliklerini azaltmış, böylece maliyeti önemli derecede düşürmüştür. Aksi durumda, ya çok daha derin kazık imalatlarına gereksinim olacak ya da hareket etmiş malzemeler inceltme kazısıyla kaldırılarak daha başka, maliyeti yüksek ve sonuçları tartışmalı olan çözümler aranmak durumunda kalınacaktı.

\section{SONUÇLAR}

Yukarıda yapılan ölçüm, gözlem ve değerlendirmelerin 1şı̆̆ında Çiğli heyelan sahasıyla ilgili aşağıdaki sonuçlara erişilmiştir:

1. Aglomeralar ve filiş taban kayasında ters ve normal fayların fay geometrileri nedeniyle bir hendek/cep oluşumu belirlenmiş ve bu cebin heyelan mekanizmasını denetlediği kanıtlanmıştır. $F_{5}, F_{1}$ ve $F_{2}$ fayları $F_{1}$ fayının fay önü düzlüğünde üç tarafı faylarla çevrili bir hendek/cep oluşturmuştur. $\mathrm{Bu}$ alan yağışı 1 mevsimlerde ve/veya aşırı beslenmelerle suya doygun hale gelmektedir (yarı basınçlı akifer oluşumu). Fay cebinin üzerinde ve altında geçirimsiz ve/veya az geçirimli zeminler yer almaktadır. $\mathrm{Bu}$ nedenle söz konusu cepte yarı basınçlı bir akiferin oluştuğu ve akiferin üzerinde yer alan $10-15 \mathrm{~m}$ kalınlığındaki heyelan malzemesinin akiferin üzerini bir tıkaç gibi örttüğü belirlenmiştir. Hareketin tamamen durdurulması, yoğun yağış alan dönemlerde fay 
cebinde biriken suların açılacak su kuyusu veya kuyularıyla heyelan sahasının dışına tahliyesiyle sağlanabilecektir.

2. Kayma dairesi aglomera ayrışma ürünü plastik killerle, kaya dokusunu korumuş, ayrışmış aglomeralar arasındaki geçiş zonu boyunca meydana gelmiştir. Kayma dairesinin, düşen blok fay cebinin (hanging wall fault pocket) üzerinden geçtiği belirlenmiştir. Cep tamamen suya doygun koşullardadır. $\mathrm{Bu}$ nedenle, hareket eden plastik kil ve siltlerin kaymasını kolaylaştırıcı yönde boşluk suyu basıncı oluşturmaktadır. Topuk bölgesinde kayma dairesi yüzeylemiştir. Ancak hareket tam tamamlanmadığı için, yüzeylediği zonda önemli makaslama deformasyonlarının gözlendiği derin bir yüzey oluşmamıştır. Heyelan progresif aşamaya geçmeden kayma hareketi önlemlerle sınırlandırılmıştır.

3. Yavaş akma şeklinde gelişen kütle hareketi (yaklaşık 4 ayda maksimum yer değiştirme $50 \mathrm{~cm}, \sim 12.5 \mathrm{~cm} /$ ay) yüzeyde gerilme çatlağ 1 , bazı binalarda ise verevine gelişmiş çatlaklar şeklinde gelişen deformasyonlara neden olmuştur. Yüzeyde gözlenen çatlaklarda en fazla açılmalar $F_{1}$ ve $F_{2}$ fayları arasında kalan göreceli genel şev açısının yüksek olduğu $\left(12^{\circ}\right.$ - $15^{\circ}$ ) arazi kesiminde meydana gelmiştir. Bina kenar dolgularının topoğrafik eğim yönündeki hareketleri, binaların her iki tarafinda yer alan kenar dolgularının heyelan hareketine farklı tepkileri nedeniyle meydana gelmiştir. Binalara yüklenen farklı gerilmeler (farklı momentler oluşturmaktadır) duvarlarda gözlenen verevine gelişmiş çatlak şeklindeki deformasyonların asıl nedenidir.

4. Jeolojik bariyer olarak $F_{2}$ ters fayının sahada olası bir derin kaymayı engellediği jeolojik ve jeoteknik çalışmalarla belirlenmiştir. Olası bir derin kaymanın fayın yükselen bloğu tarafindan önlendiği anlaşılmıştır. Burada ilginç olan; ters fayın stabiliteyi sağlayan jeolojik bir bariyer olarak ortaya çıkmış olmasıdır. Sı ̆ derinlikte (8-15 m) gelişen heyelanın önlenmesine yönelik önerilen kazık grubunun yer seçiminde de ters fayın sağlam kaya özelliğindeki yükselen bloğu yarar sağlamıştır. Çünkü, heyelanı önlemek üzere önerilen kazık imalatları bu bölgeye yapılmış ve bu uygulamadan önemli bir ekonomi sağlanmıştır.

\section{KAYNAKLAR}

Akartuna, M., 1962. On the geology of Izmir, Torbal1, Seferhisar, Urla districts. MTA Bulletin, 5, 1-19.

Akgün, A., Kıncal, C., Pradhan, B., 2012. Application of remote sensing data and GIS for landslide risk assessment as an environmental threat to İzmir city (west Turkey). Environmental Monitoring and Assessment, 184, 5453-5470.

ASTM 1971. Standard test method for plastic limit and plasticity index of soil. D. 424-59, 127-128.

ASTM 1979a. Standard test method for direct shear test of soils under consolidated drained conditions. D. 3080-72, 487-497.

ASTM 1979b. Standard test method for unconfined compressive strength of cohesive soils. D. 216667, 332-335.

ASTM D0422-63, 2007. Test method for particlesize analysis of soils. Annual book of ASTM standards, section 4, Vol. 04.08, soil and rock, building stones. ASTM International, West Conshohocken, PA.

ASTM D4622-86, 1993. Standard test method for rock mass monitoring using inclinometers (Withdrawn 2000), in soils. ASTM International, West Conshohocken, PA.

ASTM D4719 2000. Standard test method for prebored pressuremeter testing in soils. ASTM International, West Conshohocken, PA.

Bishop, A. W., 1955. The use of the slip surface in stability analysis of slopes. Geotechnique, 5 (1), 7-17.

Kıncal, C., 2005. İzmir İç Körfezi çevresinde yer alan birimlerin coğrafi bilgi sistemleri ve uzaktan 
algılama teknikleri kullanılarak mühendislik jeolojisi açısından değerlendirilmesi. Dokuz Eylül Üniversitesi, Fen Bilimleri Enstitüsü, İzmir, Doktora Tezi, $342 \mathrm{~s}$.

Kıncal, C., Akgün, A., Koca, M. Y., 2009. Landslide susceptibility assessment in the İzmir (West Anatolia, Turkey) city center and its near vicinity by the logistic regression method. Environmental Earth Sciences, 59, 745-756.

Koca, M. Y., 1995. Slope stability assessment of the abandoned andesite quarries in and around the Izmir city centre. The Graduate School of Natural and Applied Sciences of Dokuz Eylul University, İzmir, PhD Thesis, $430 \mathrm{p}$.

Koca, M. Y, Kıncal, C., 2004. Abandoned stone quarries in and around the Izmir city centre and their geo-environmental impacts -Turkey. Engineering Geology, 75, 49-67.
Köse, G., 2007. Grafitli şeyl ayrışma ürünü killer ve kaymaya olan etkileri, örnek çalışma: Narlıdere heyelan bölgesi. Dokuz Eylül Üniversitesi Fen Bilimleri Enstitüsü, İzmir, Yüksek Lisans Tezi, $114 \mathrm{~s}$.

Rocscience, 2010. Slide: Stability analysis for soil and rock slopes. Rocscience, Toronto.

Tarcan, G., Koca, M. Y., 2001. Hydrogeological and geotechnical assessments of the Kadifekale landslide area, İzmir, Turkey. Environmental Geology, 40 (3), 289-300. 
